Journal of Educational

and Psychological Sciences

Volume (5), Issue (25): 30 Jul 2021

P: 80 - 104

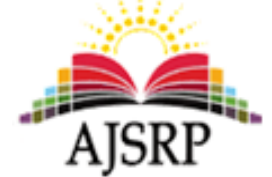

ISSN: 2522-3399
مجلة العلوم

التربوية والنفسية

المجلد (5)، العدد (25): 30 يوليو 2021 م

ص: 80 - 104

\title{
The effect of using the social network (Twitter) in teaching on the achievement of first-grade secondary students in the subject of research skills and information sources in Hafar Al-Batin Governorate
}

\author{
Sulaiman Khalaf Alshammary \\ Department of Education in Hafar Al-Batin Governorate \| Ministry of Education || KSA
}

\begin{abstract}
This study aimed to investigate the effect of the use of social networks (Twitter) on the academic achievement level of the first year of secondary students in the course of research and sources of information skills and to achieve the objectives of the study, the researcher prepares a study tool which is about achievement test to determine the level of student achievement in cognitive levels lower in classification Bloom (remembering, understanding, application) separately, and also in the overall achievement test and applied study on a random sample of first-grade secondary students Hafr Albatin numbered 50 students have reached the researcher to the following results:

-There are statistically significant differences at the level of significance (0.05) in the average student achievement in the decision of research skills and sources of information between the control group and experimental in the post application when remembering, understanding and application of each separately for the experimental group was taught using Twitter levels.

-There are statistically significant differences at the level of significance (0.05) in the average student achievement in the decision of research skills and sources of information between the control group and the experimental application in the post in the overall achievement test for the experimental group was taught using Twitter.

In light of the findings, the researcher developed a number of recommendations represent the most important in the following:

activation of teaching using social networks (Twitter) in the decisions of the research skills and sources of information in all classrooms
\end{abstract}

Keywords: academic achievement- social networks- Twitter- education- research skills and information sources.

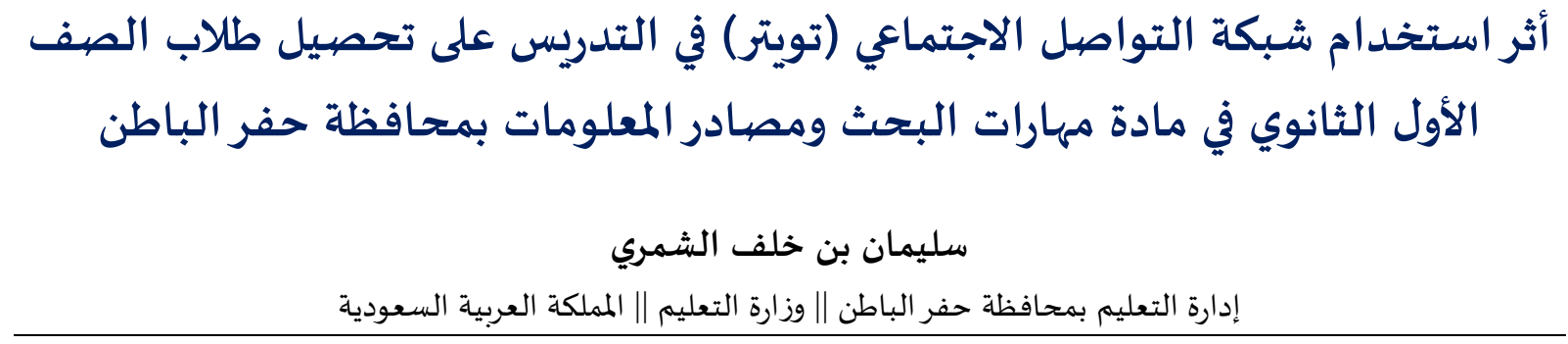

المستخلص: هدفت الدراسة إلى معرفة أثر استخدام شبكات التواصل الاجتماعي ( تويتر)على مستوى التحصيل الدراسي لدى طلاب

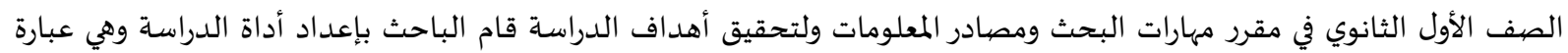
عن اختبار تحصيلي لتحديد مستوى تحصيل الطلاب في المستويات المعرفية الدنيا في تصنيف بلوم (التذكر، الفهم، التطبيق)كل على مهلى 
حدة، وأيضا في مجمل الاختبار التحصيلي واستخدم الباحث المنهج شبه التجريبي وطبقت الدراسة على عينة عشوائية من طلاب الصف

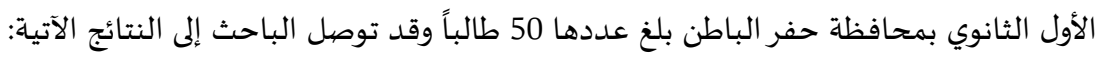

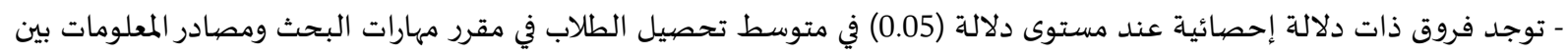

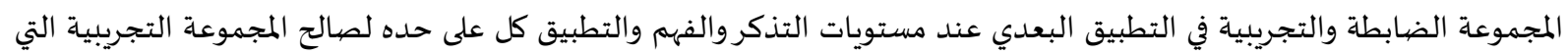
تم تدريسها باستخدام تويتر.

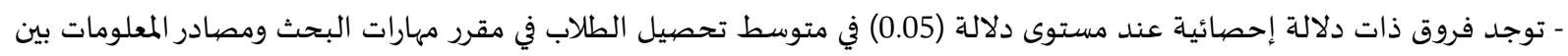

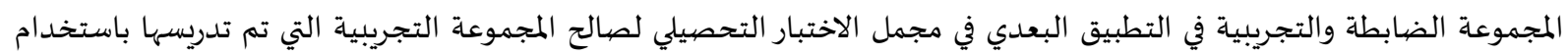

وفي ضوء النتائج قدم الباحث عدداً من التوصيات أهمها تمثل في الآتي: - تفعيل التدريس باستخدام شبكات التواصل الاجتماعي (تويتر) في مقررات مهارات الباتي البحث ومصيادر المعلومات في جميع الصفوف التعليمية. - تقديم دورات تدريبية للمعلمين والمشرفين التربويين لتطوير أدائهم في استخدام الأدوات التي يتيحها ويب 2.0 بشكل عام وشبكات التواصل الاجتماعي بشكل خاص والافادة منها في تدريس المقررات الدراسية.

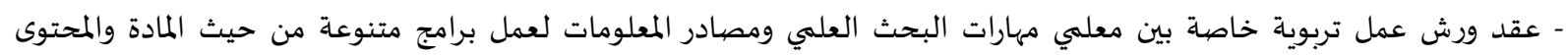
الدراسي وإثراء الهاشتاغات المنهجية والأنشطة الخاصية بالمقرر

الكلمات المفتاحية: التحصيل الدراسي - شبكات التواصل الاجتماعي - تويتر - التعليم - مهارات البحث ومصادر المعلومات.

مقدمة:

تعتبر التربية من أهم دعائم المجتمع في الهوض بأبنائه في كافة المراحل التعليمية المختلفة، وهي من أقوى

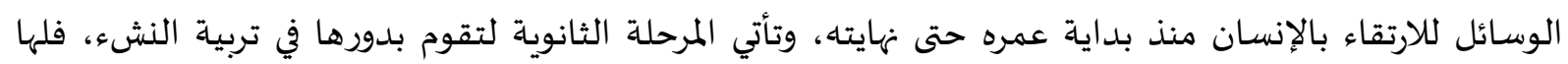

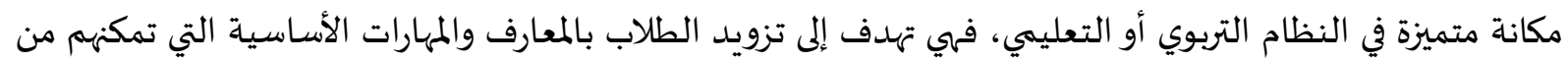

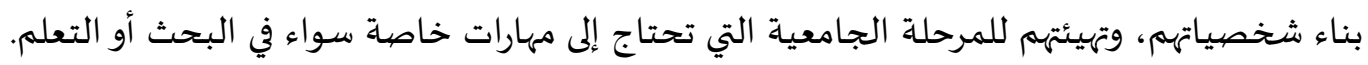

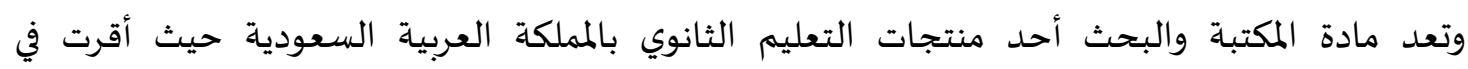
1413/4/17 هـ بموجب تعميم وزير المعارف آنذاك رقم 49/243 واستمر العمل بتطوير هذه المادة بما يلائم كل فترة زمنية معاصرة، إلى أن استقرت على المسهى الجديد وهو مهارات البحث ومصادر المعلومات ضمن فيمن مشروع نظام

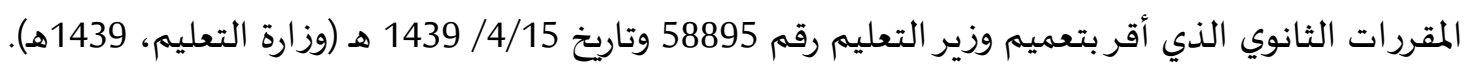

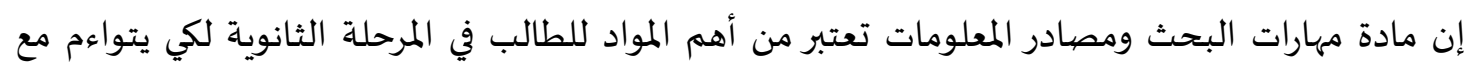

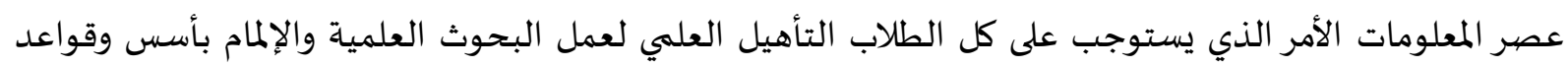

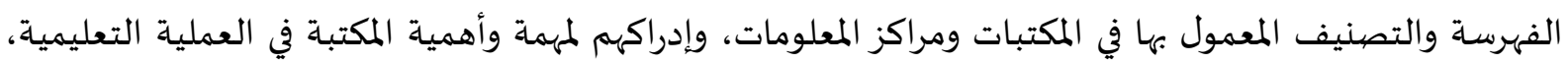

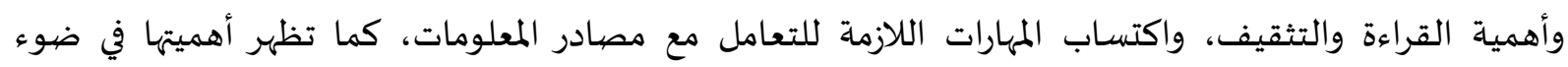

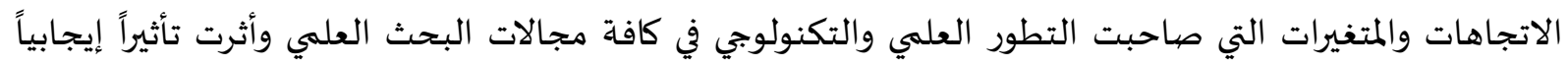

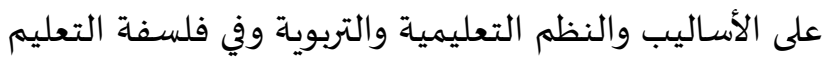
ومن الملاحظ بأن تحقيق أهداف مادة مهارات البحث ومصادر المعلومات تحتاج إلى أساليب حديثة ومتطورة ولئي

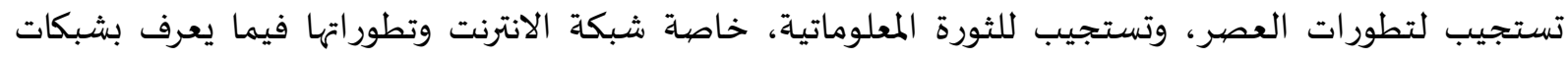
التواصل الاجتماعي.

لقد فرضت شبكات التواصل الاجتماعي وجودها واندماجها في حياة الناس، الأمر الذي شجع البعض على استخدامها في مؤسسات التعليم، فعلاوة على وجود نظريات في علم النفس تدعم استخدامها خاصية النظرية 
الاتصالية التي ترتبط بالمستحدثات التكنولوجية حيث يمكن تطبيق مبادئ الاتصالية من خلال المستحدثات

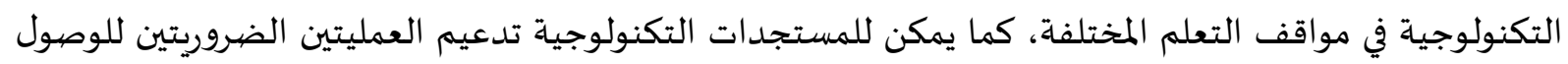

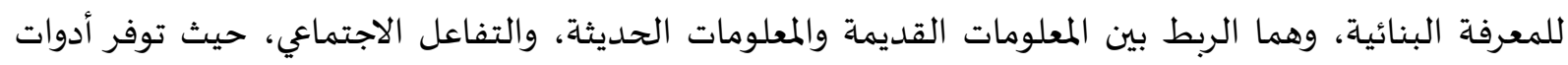

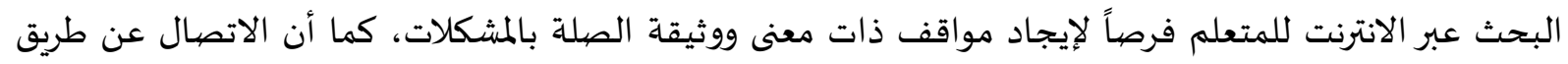

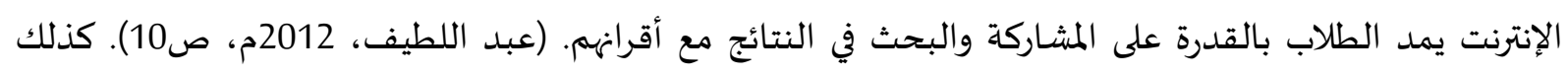

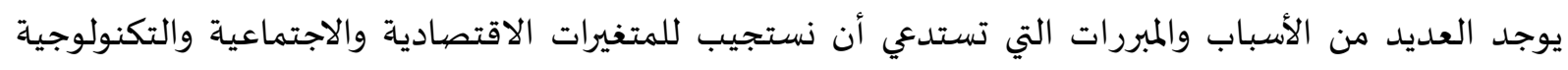
والثقافية الموجودة في المقررات الدراسية ومنها مقرر مهارات البحث ومصادر المعلومات، فاتساع المعاع الفجوة المبات الرقمية بين

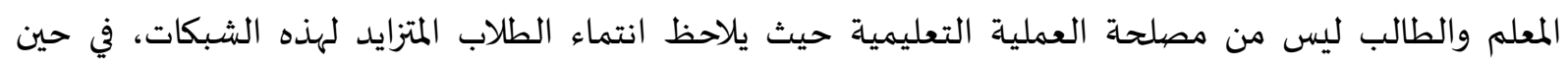

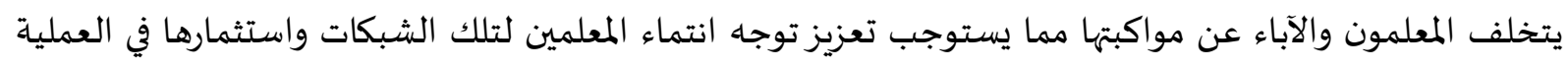

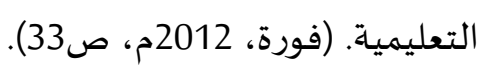

وفي منتصف التسعينيات، ظهر مصطلح التعليم الإلكتروني وذلك نتيجة الانتشار الواسع لتكنولوجيا

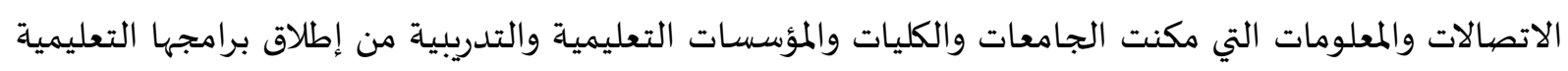

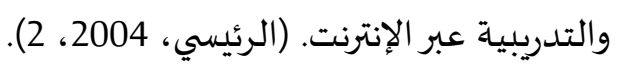

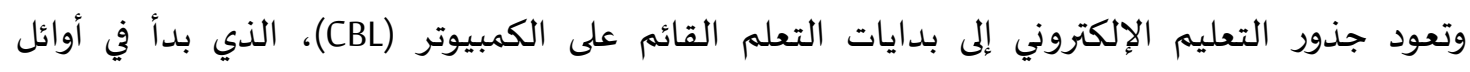

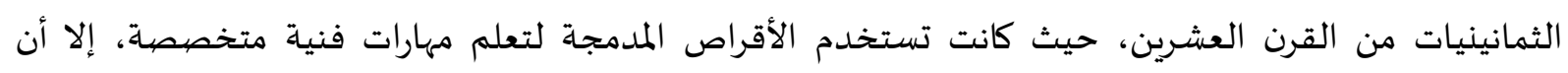

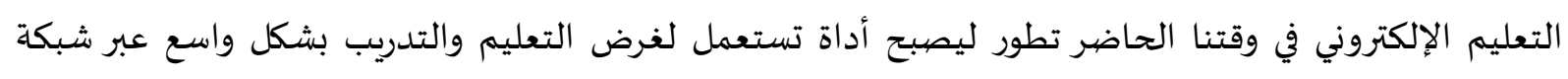

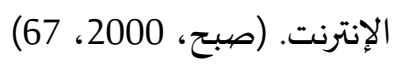
ولوجود حاجة لدراسات تتحدث عن إمكانية تأثير استخدام وتوظيف شبكات التواصل الاجتماعي في

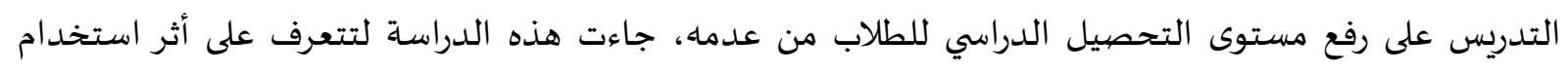

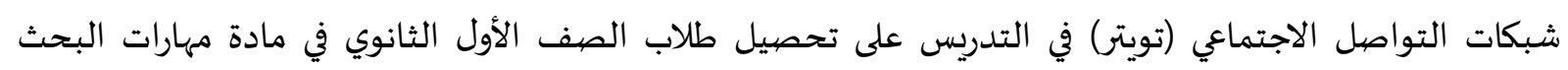
ومصادر المعلومات بمحافظة حفر الباطن من خلال دراسة نظرية وميدانية خضعت التئ للمنهج شبها التجريبي.

مشكلة الدراسة: لقد حدث جدل واسع بين التربويين حول تأثير استخدام شبكات التواصل الاجتماعي على التحصيل الدراسي

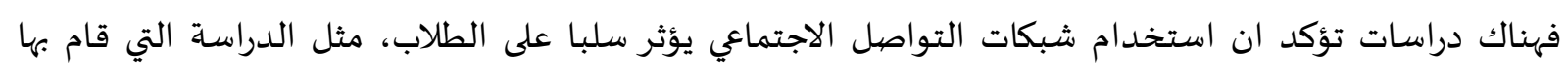
(ketari \& khanum،2013) وفي المقابل هناك دراسات تؤكد على ان استخدام شبكات التواصل الاجتماعي لا يؤثر على التحصيل

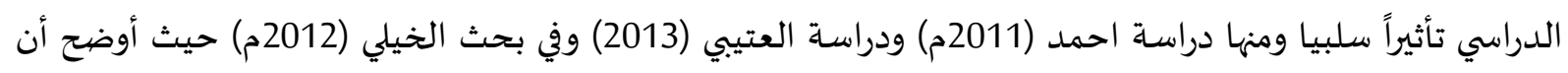

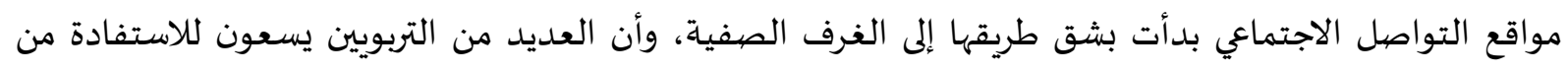

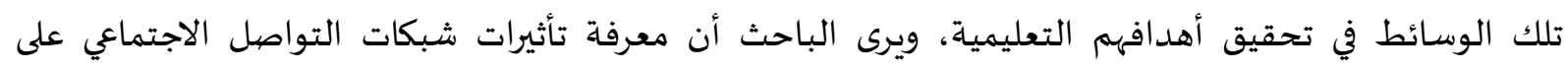

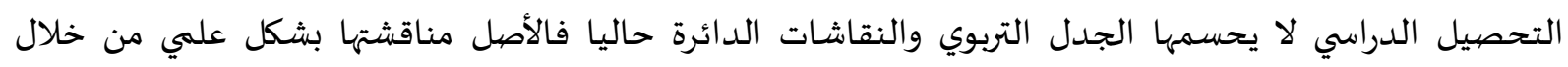

$$
\text { البحوث والتجارب العلمية التحمية التراسية }
$$

يمكن صياغة مشكلة الدراسة في التساؤلات التالية: 
1- هل توجد فروق ذات دلالة إحصائية عند مستوى دلالة (0.05) في متوسط تحصيل الطلاب في مقرر مهارات البحث ومصادر المعلومات للصف الأول الثانوي بمحافظة حفر الباطن بين المجموعتئن داندين التجريبية والضيابطة

$$
\text { عند المستوى المعرفي الأول في تصنيف بلومات لاتهف (التذكر)؟ }
$$

2- هل توجد فروق ذات دلالة إحصائية عند مستوى دلالة (0.05) في متوسط تحصيل الطلاب في مقرر مهارات البحث ومصادر المعلومات للصف الأول الثانوي بمحافظة حفر الباطن بين المجموعتين التجريبية والضيابطة

$$
\text { عند المستوى المعرفي الثاني في تصنيف بلوم (الفهم)؟ }
$$

3- هل توجد فروق ذات دلالة إحصائية عند مستوى دلالة (0.05) في متوسط تحصيل الطلاب في مقرر مهارات البحث ومصادر المعلومات للصف الأول الثانوي بمحافظة حفر الباطن بين المجموعتين التجريبية والضيابطة دانة عند المستوى المعرفي الثالث في تصنيف بلوم (التطبيق)؟ 4- هل توجد فروق ذات دلالة إحصائية عند مستوى دلالة (0.05) في متوسط تحصيل الطلاب في مقرر مهارات

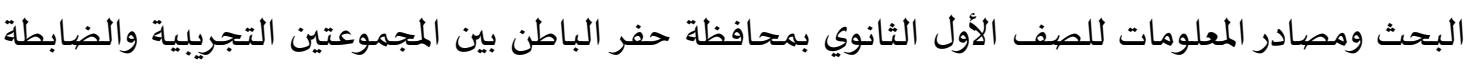
في مجمل الاختبار التحصيلي؟

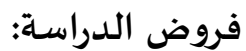
1- ل لا توجد فروق ذات دلالة إحصائية عند مستوى دلالة (0.05) في متوسط تحصيل الطلاب في مقرر مهارات

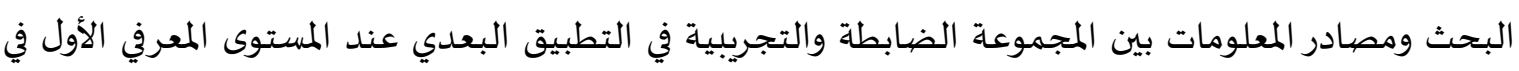
تصنيف بلوم لصالح المجموعة التجريبية التي تم تدريسها باستخدام شبكة التواصل الاجتماعي تويتر. 2- لا توجد فروق ذات دلالة إحصائية عند مستوى دلالة (0.05) في متوسط تحصيل الطلاب في مقرر مهارات

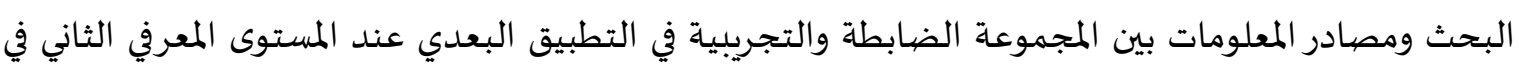
تصنيف بلوم (الفهم) لصالح المجموعة التجريبية التي تم تدريسها باستخدام تويتر. 3- لا توجد فروق ذات دلالة إحصائية عند مستوى دلالة (0.05) في متوسط تحصيل الطلاب في مقرر مهارات

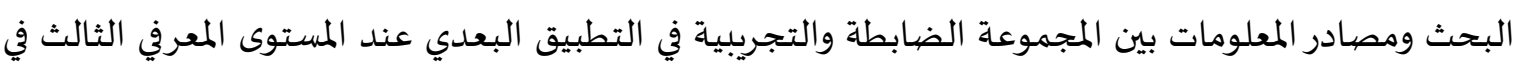

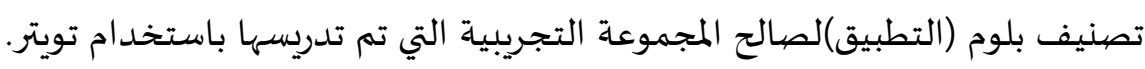

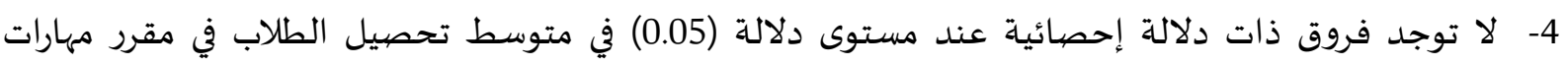

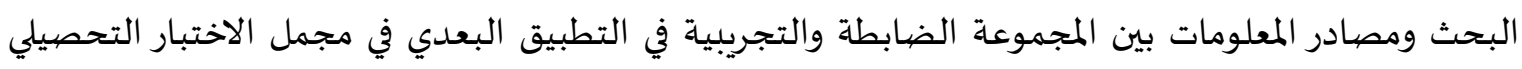
لصالح المجموعاة التجريبية التي تم تدريسها باستخدام شبكاة التواصل الاجتماعي تويتر.

أهمية الدراسـة: 1. تقديم رؤية واضحة لطريقة توظيف شبكة التواصل الاجتماعي (تويتر) داخل الصف الدراسي وخارجه وفي أي

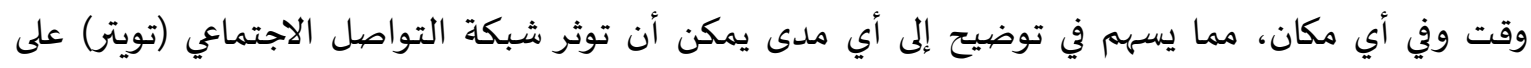
التحصيل الدراسي لدى الطلاب. 2. تبين الدراسة الحالية طريقة جديدة للتعلم تعتمد على شبكات التواصل الاجتماعي من خلال تقديم خلفية علمية عن استخدام شبكات التواصل الاجتماعي في التعليم بشكل عام وشبكة التواصل الاجتماعي (تويتر) بشكل خاص. 3. إطلاع المسؤولين عن التعليم الثانوي والمناهج في وزارة التعليم وفي إدارة التعليم بمحافظة حفر الباطن على التئ

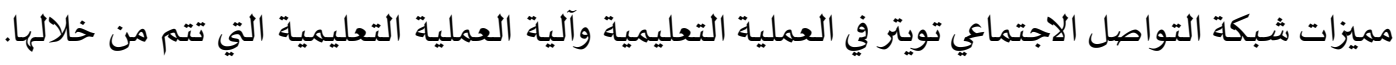


4. - الإسهام في تغطية النقص في الدراسات بهذا المجال 5. تساعد نتائج هذه الدراسة متخذي القرار في وزارة التعليم وخاصة واضعي المناهج في بناء واعداد البرامج التربوية الهادفة من خلال شبكات التواصل الاجتماعي لتوظيفها في خدمة العملية التعليمية التعلمية.

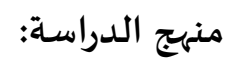

المنهج الملائم للكشف عن أثر استخدام شبكات التواصل الاجتماعي (تويتر) في التدريس على تحصيل طلاب

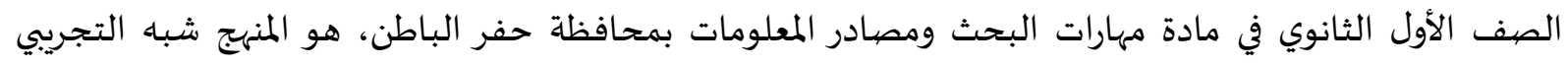

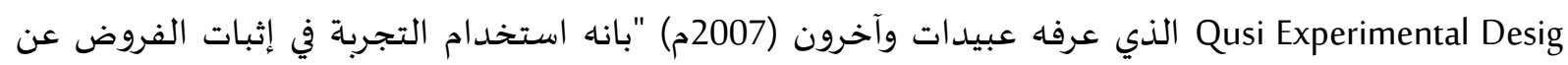

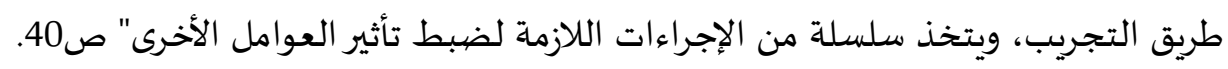

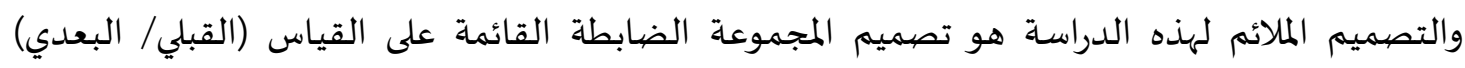

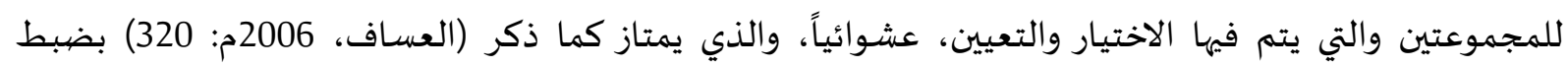

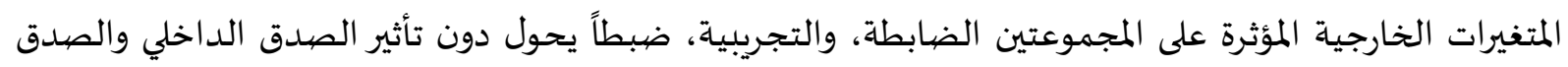

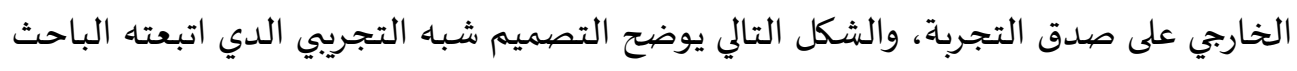

$$
\begin{aligned}
& \text { أدوات الدراسة: } \\
& \text { 1- الاختبار التحصيلي في مادة مهارات البحث ومصادر المعلومات }
\end{aligned}
$$

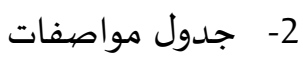

$$
\begin{aligned}
& \text { 3- - 2 دليل المعلم }
\end{aligned}
$$

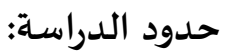

الحدود الموضوعية: أثر استخدام شبكة التواصل الاجتماعي (تويتر) في التدريس على التحصيل في مادة مهارات

$$
\text { البحث ومصادر المعلومات (تقنية المعلومات). }
$$

الحدود البشرية: المستوى الثاني للصف الأول الثانوي باستخدام شبكة التواصل الاجتماعي (تويتر).

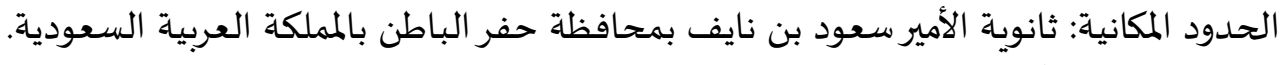

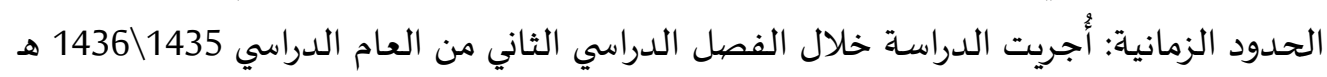

الإطار النظري للدراسـة

تم تقسيم هذه الدراسة إلى

أولا: الإطار النظري

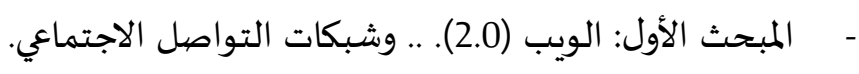

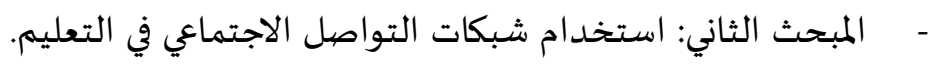

- - -

ثانياً: الدراسـات السـابقة.

- - المحور الأول: دراسات تناولت استخدام شبكات التواصل الاجتماعي في التعليم. - - التعقيب على الدراسات السـابقة في المحور الأول. 
- المحور الثاني: دراسات تناولت العلاقة بين استخدام شبكات التواصل الاجتماعي والتحصيل الدراسي. المحور الثالث التعقيب على الدراسات السابقة في المحور الثاني.

الدراسات السابقة:

من خلال مراجعة الدراسات السابقة ذات الصلة بموضوع الدراسة الحالية تم تقسيمها إلى محورين دراسات تناولت استخدام شبكات التواصل الاجتماعي في التعليم، ودراسات تناولت العلاقة بين استخدام شبكات التواصل الاجتماعي والتحصيل الدراسي، وقد تم تناول الدراسات بعرض ملخص لكل دراسة يتضمن هدف الدراسية

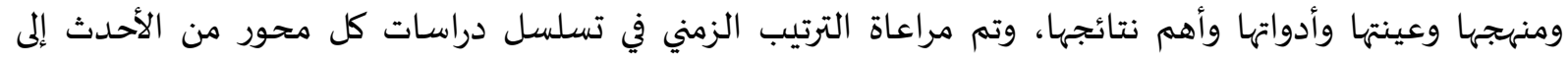
الأقدم.

دراسة (الحمد، 2014م) هدفت الدراسة إلى التعرف إلى دور شبكات التواصل الاجتماعي في دعم المنظومة التعليمية لدى طلاب كلية التربية في جامعة أم القرى، واستخدم الباحث المنهج الوصدية الوصفي، وأختار العينة

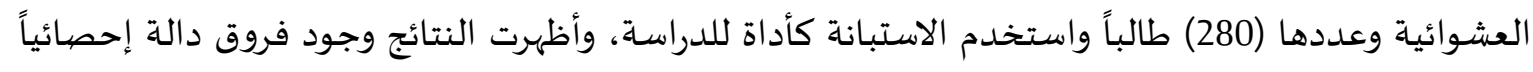

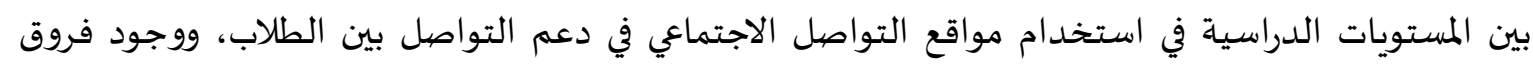

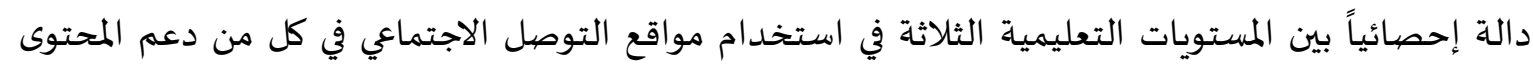

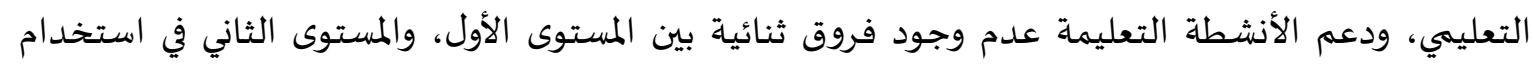

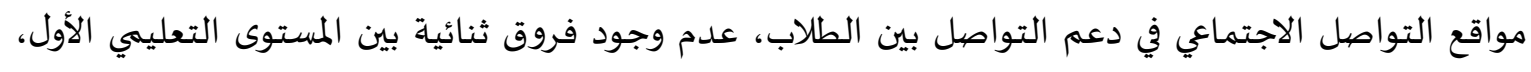

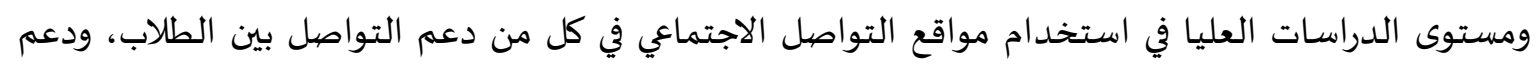

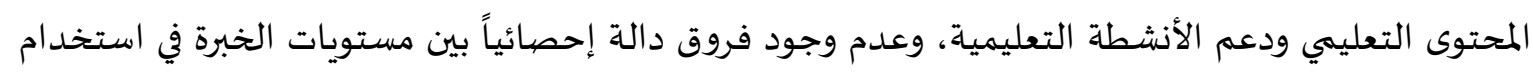

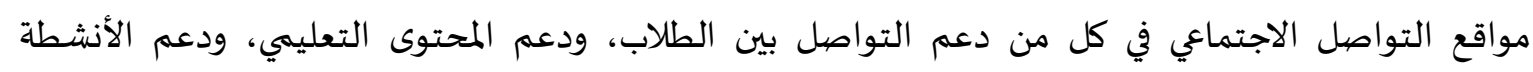

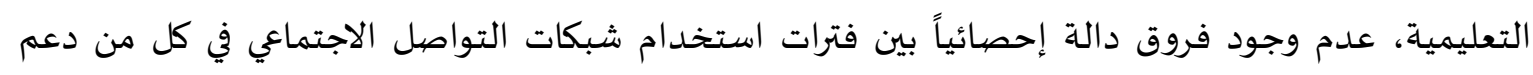

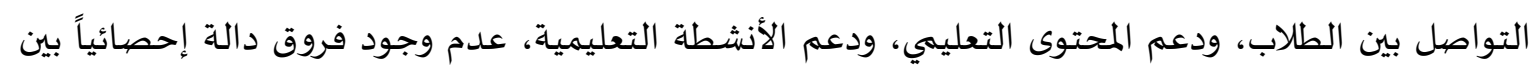

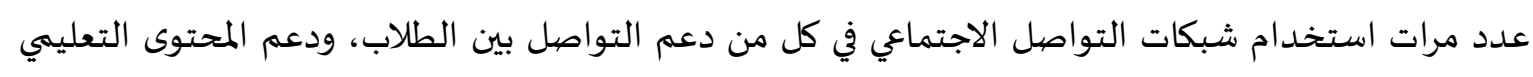
ودعم الأنشطة التعليمية. دراسة (العنزي، 2014م) سعت إلى التعرف على مفهوم شبكات التواصل الاجتماعي وأهميتها بالنسبة للمجتمع

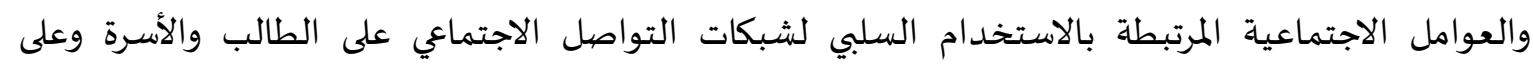

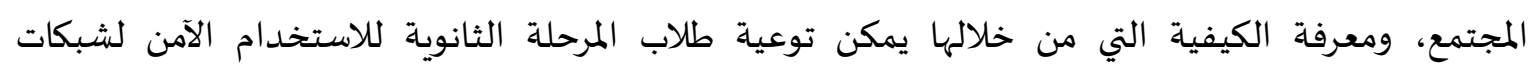

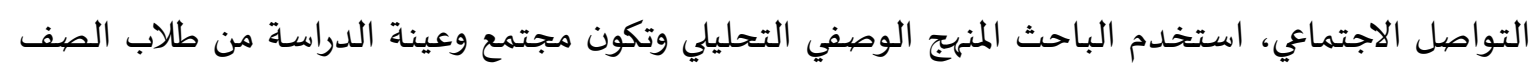

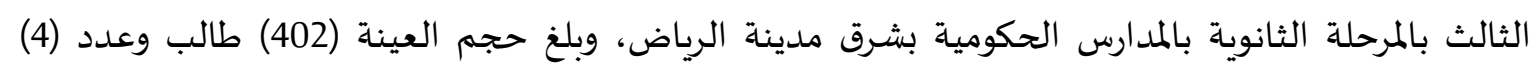

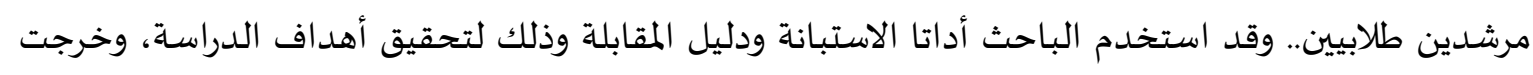

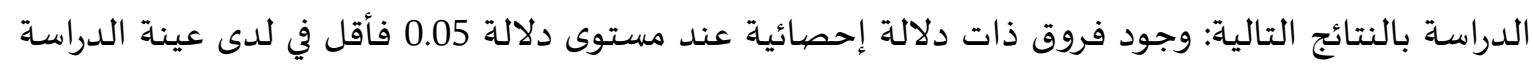

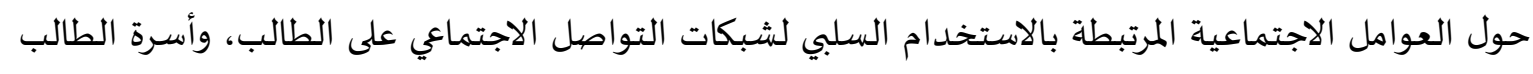

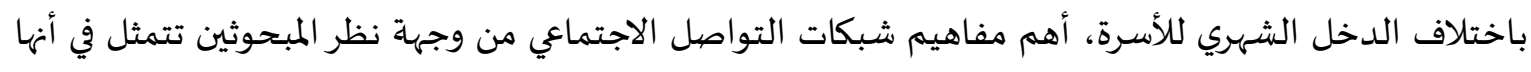

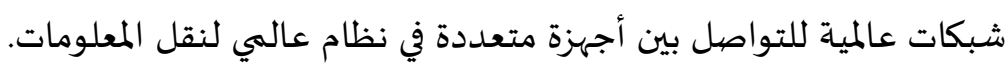
دراسة (العتيبي، 2013م) هدفت الدراسة إلى التعرف فاعلية شبكة التواصل الاجتماعي تويتر (التدوين

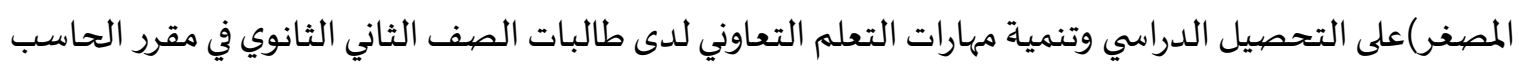


الآلي، وأعتمدت على المنهج شبه التجريبي القائم على التصميم (القبلي-البعدي) للمجموعتين التجريبية والضابطة ولإجابة على أسئلة واختبار فرضيات الدراسة، وتكونت عينة الدراسة من (60) طالبة تم اختيارهن

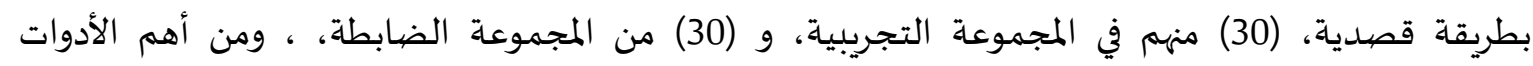

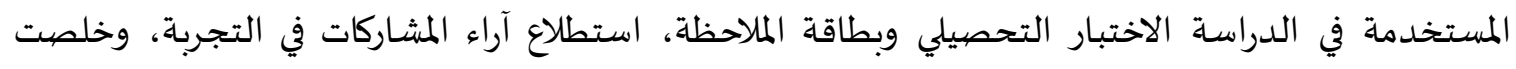

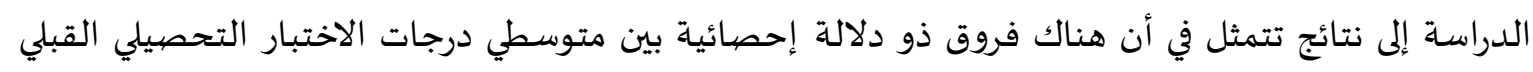

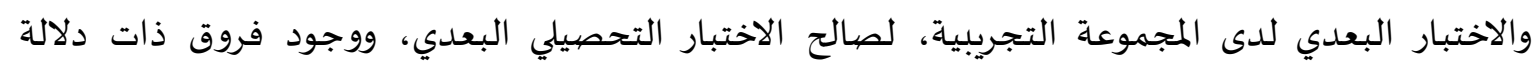

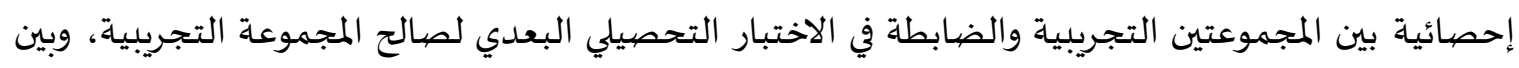

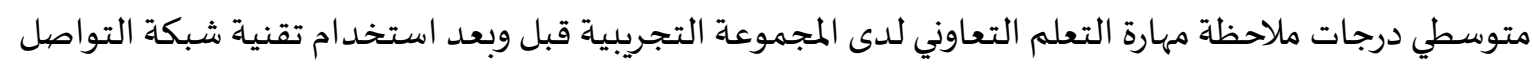
الاجتماعي تويتر لصالح درجات الملاحظة البعدي. دراسة (العطاس، 2014م) التي هدفت للتعرف على اثر التدريس عبر شبكة التواصل الاجتماعي (فيسبوك) على

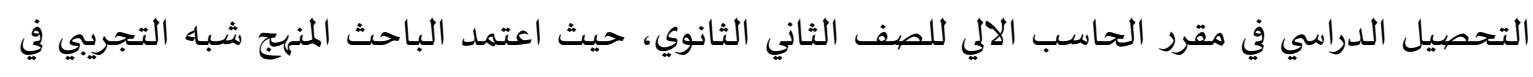

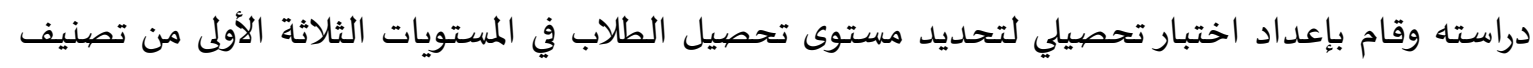

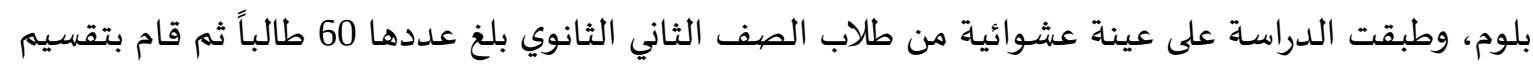

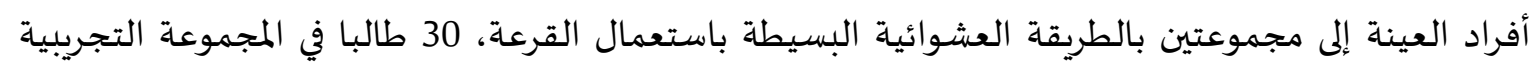

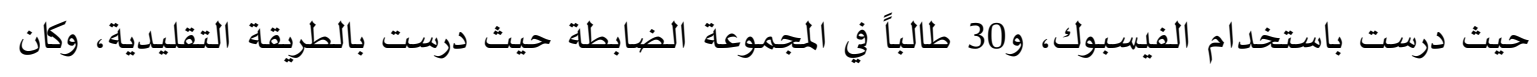

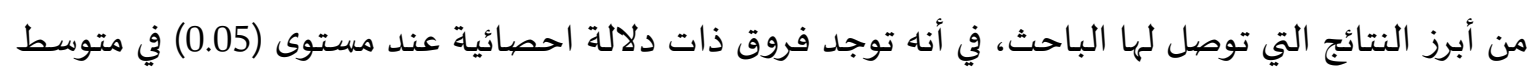

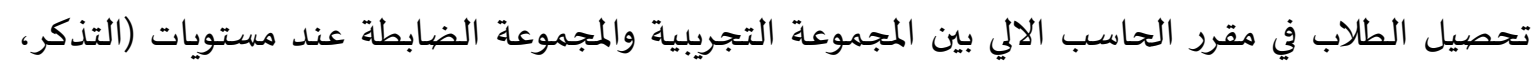

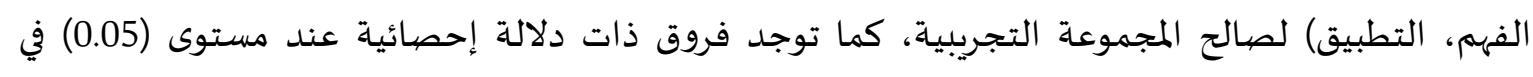
متوسط تحصيل الطلاب في مقرر الحاسب الالي بين المجموعة التجريبية والمجموعة الضابطة في مجمل المجلية الاختبار التحصيلي لصالح المجموعة التجريبية.

التعقيب على الدراسـات السابقة من خلال استعراض الدراسات السابقة حول موضوع الدراسـة الحالية أتضح أن الدراسات السابقة تناولت

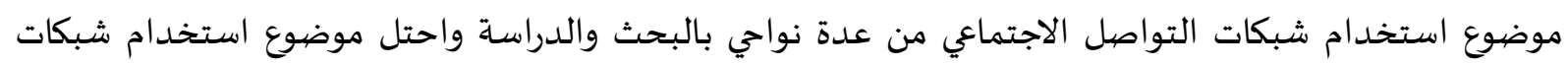

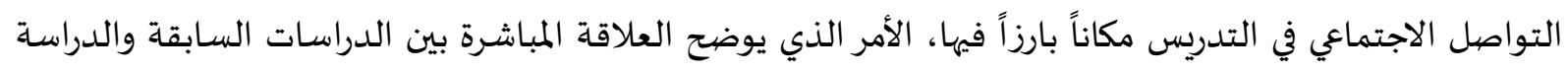

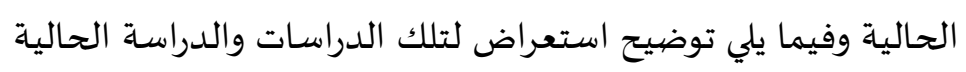

يتضح من عرض الدراسات السابقة أهمية استخدام شبكات التواصل الاجتماعي في التعليم حيث بينت

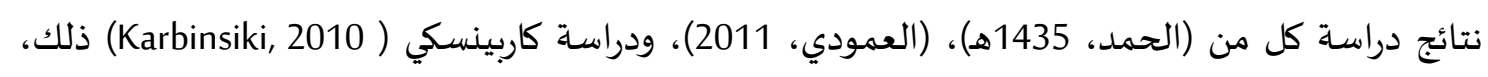
وهو ما يتفق مع هذه الدراسة دونة

تؤكد بعض الدراسات السابقة على أن هناك دور لشبكات التواصل الاجتماعي في حل المشكلات التي تواجه

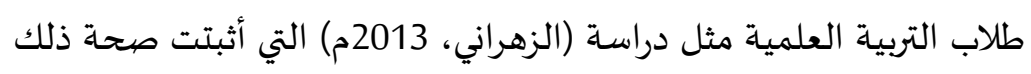
تبين بعض الدراسات وجود تباين في درجة استخدام مواقع التواصل الاجتماعي مثل دراسة (الرشيدي،

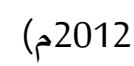

أجريت معظم الدراسات السابقة خلال الخمس سنوات الأخيرة، مما يدل على حداثة موضهوع الدراسة

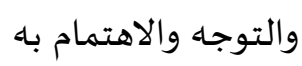




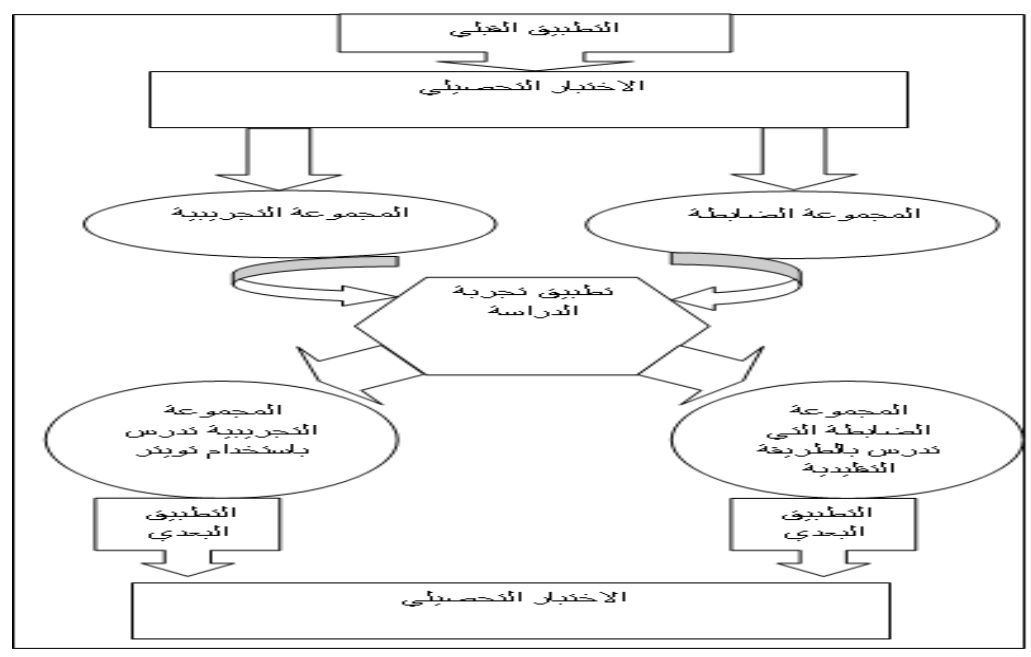

شكل رقم (1) التصيميم التجريبي لتجبربة الدراسة

وبناء عليه قام الباحث وفق هذا التصيميم بتطبيق أدوات الدراسة (الاختبار التحصيلي القبلي) على ملى ملهربه

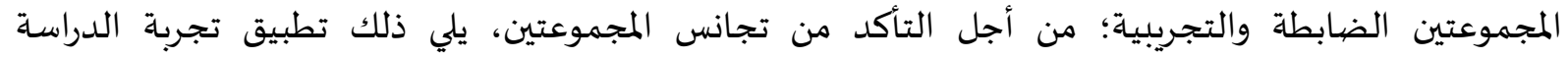

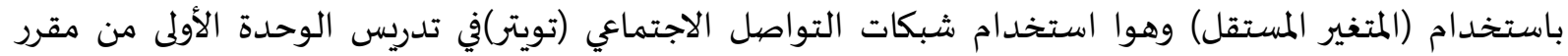
مهارات البحث ومصادر المعلومات على المجموعة التجريبية، في حين تركت المجموعة الضابطة تدرس بالطريقة المعتادة، وبعد الانتهاء من تطبيق التجربة والتي استغرقت ما يقارب من أربعة أسابيع؛ تم تطبيق (الاختبار التحصيلي

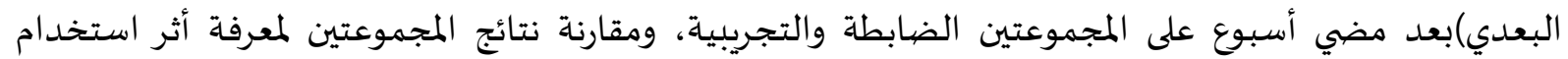
شبكات التواصل الاجتماعي (تويتر) في التحصيل.

مجتمع الدراسة: مجتمع الدراسة كما يعرفه عبيدات وآخرون (2007) " هو جميع الأشخاص أو الأفراد الذين يكونون مشكاة

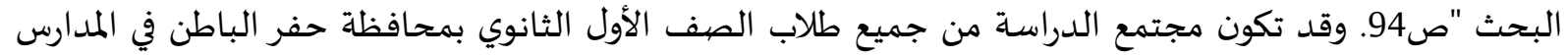

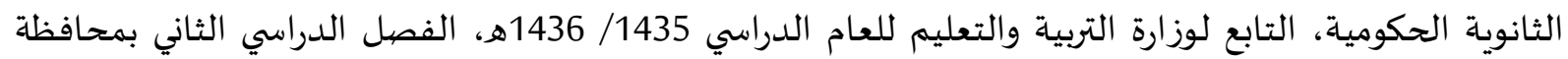

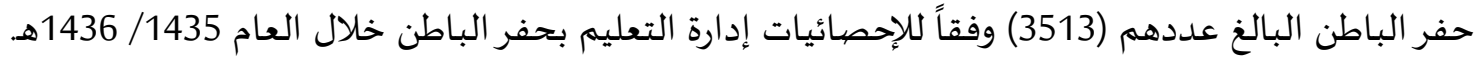

عينة الدراسة:

قام الباحث باختيار عينة عشوائية بسيطة من مجتمع الدراسة وفق الخطوات التالية:

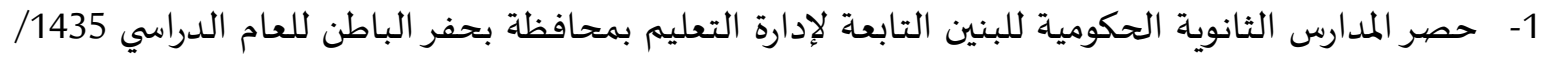

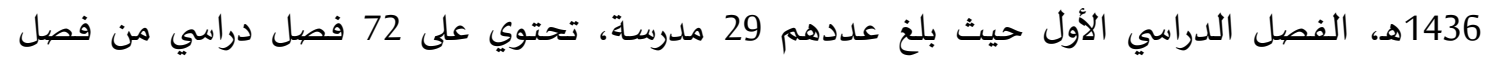

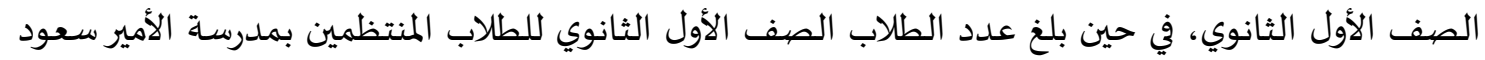
بن نايف بمحافظة حف الباطن في تلك الفصول 50 طالباً، وبذلك يكون معدل الطلاب 25 طالب في كل فصل. 2- الاختيار العشوائي البسيط لمدرسة واحدة من بين هذه المدارس بطريقة الفرص المتساوية؛ والتي تعني إجراء

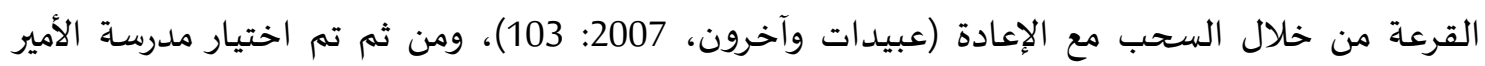
سعود بن نايف بمحافظة حف الباطن بحفر الباطن. 
3- الاختيار العشوائي البسيط لمجموعتين من الطلاب بالصف الأول الثانوي إحداهما تمثل المجموعة الضابطة،

$$
\text { والأخرى تمثل المجموعة التجريبية. }
$$

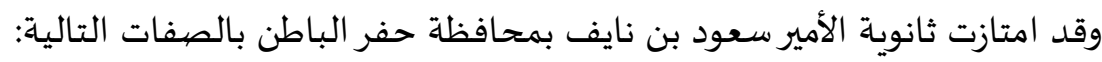

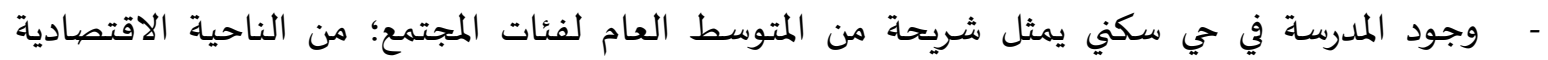

والاجتماعية والثقافية.

$$
\begin{aligned}
& \text { - عدد طلاب المدرسة مناسب لإجراء التجربة. } \\
& \text { تعاون الإدارة مع الباحث وترحيههم بإجراء الدراسة في مدرستهم. } \\
& \text { توفر الامكانيات اللازمة لتطبيق التجربة. }
\end{aligned}
$$

وقد بلغ عدد طلاب الصف الأول الثانوي بمدرسة ثانوية الأمير سعود بن نايف بمحافظة حفر الباطن (50)

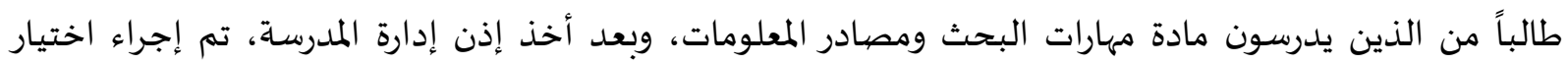

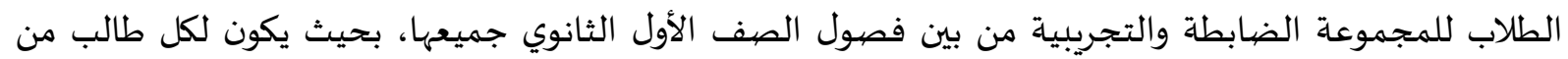

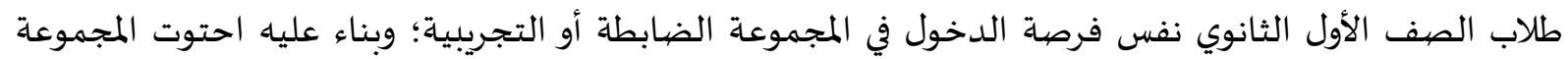
الضابطة على (25) طالب من طلاب الصف الأول، مقابلهم (25) بالمجموعة التجريبية، وبذلك أصبحت العبدانة العينة وحدتها الفرد، وهذا أقوى في تحقيق الاختيار العشوائي.

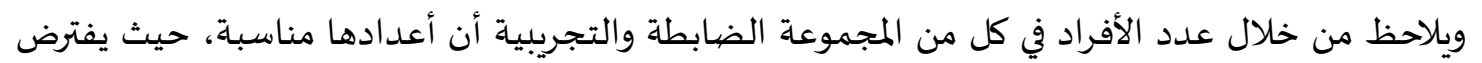

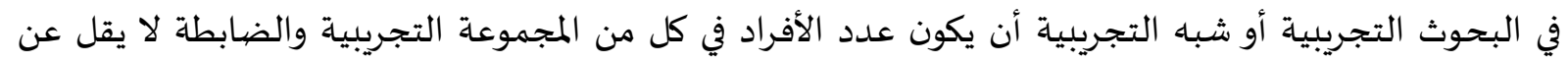

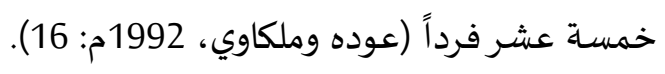

$$
\text { متغيرات الدراسة: }
$$

$$
\text { تمثلت متغيرات الدراسـة فيما يلي: }
$$

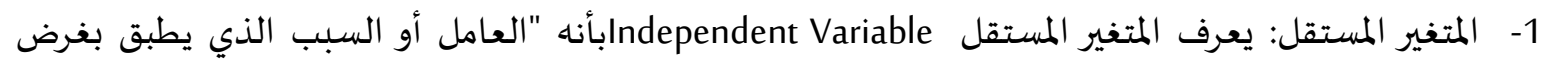

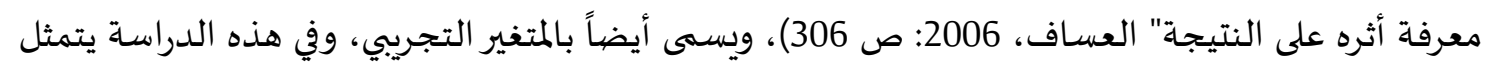

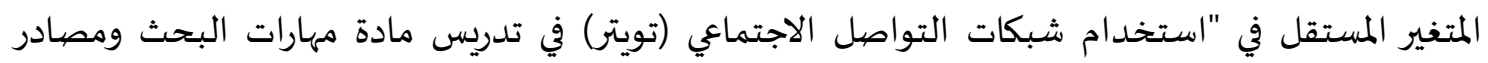

$$
\text { المعلومات. }
$$

2- المتغير التابع DEpendet Variable: هو النتيجة "التي يقاس أثر تطبيق المتغير المستقل عليها" (العساف،

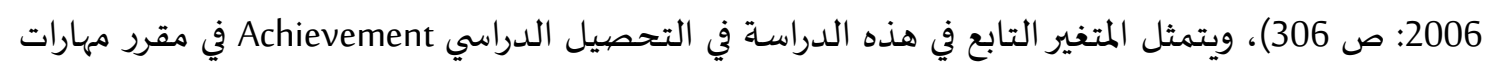

$$
\text { البحث ومصادر المعلومات لطلاب الصف الأول الثانوي. }
$$

أداة الدراسة (اختبار تحصيلي إعداد الباحث): عرفها العساف (2006) "بأنه ما صهمم لتقدير ما حصل عليه الطالب من المبارتحفئ المعلومات التي تعلمها أو المهارات

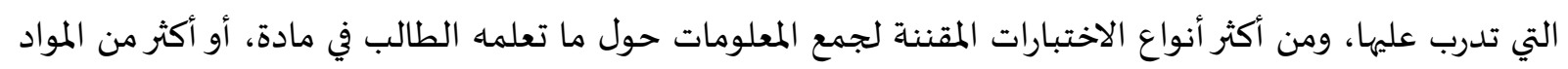

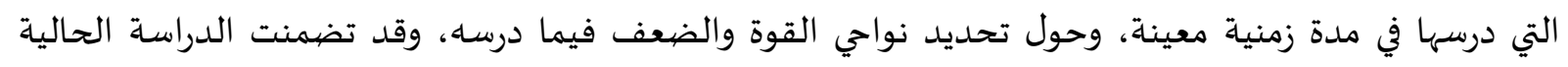

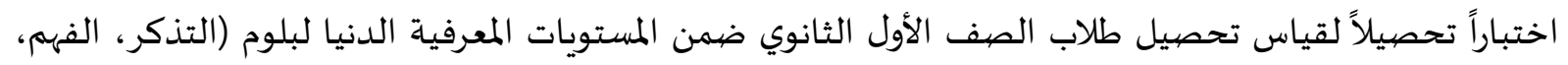

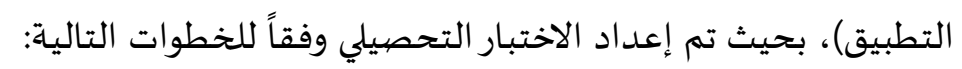

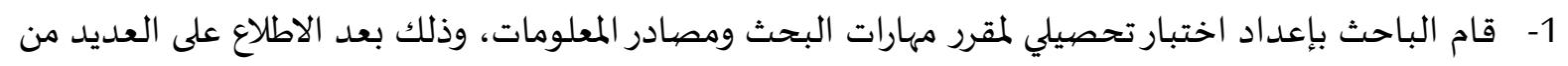

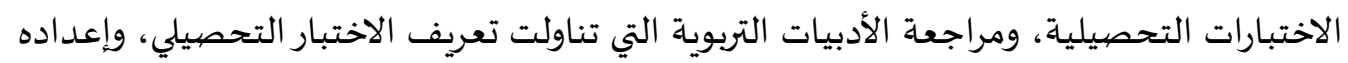


2- 2 - الهدف من الاختبار التحصيلي:

هدف الاختبار التحصيلي إلى قياس التحصيل في الوحدة الأولى (تقنية المعلومات) في مقرر مهارات البحث التحث

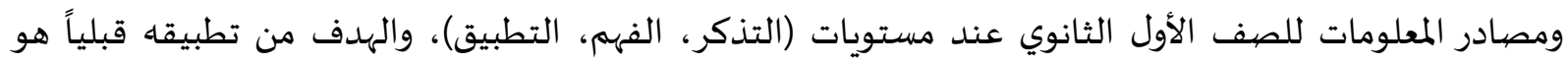

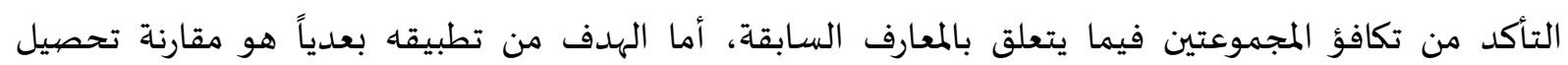

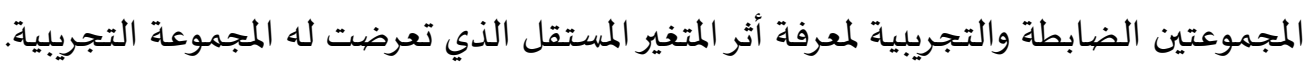

$$
\text { 3- تحديد الأهداف التعليمية: }
$$

قام الباحث بإعداد قائمة بالأهداف الإجرائية لتكون منطلقاً لبناء الاختبار التحصيلي وبلغت الأهداف في

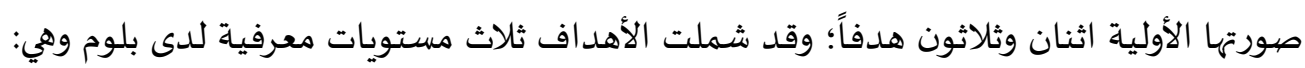

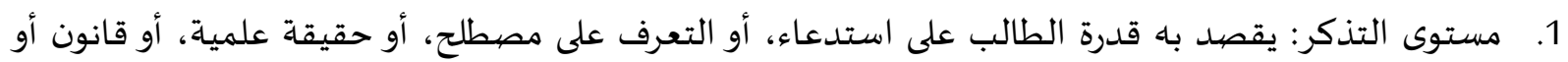

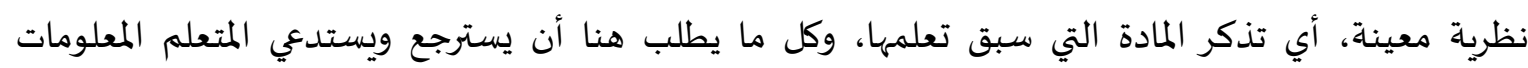

$$
\text { المطلوبة (مازن، 1430هـ: 61). }
$$

2. مستوى الفهم: وهو القدرة على إدراك المادة التي يدرسها المتعلم، ويظهر هذا عن طريق ترجمة المادة من صورة

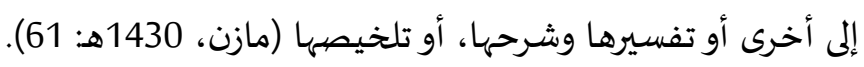

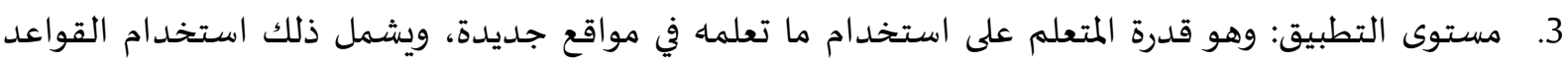

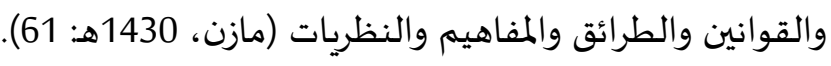

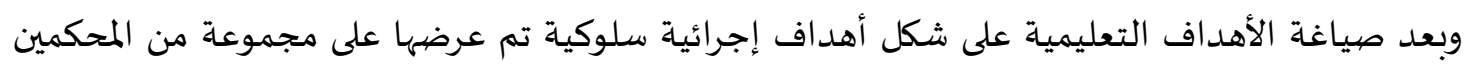

من منسوبي الجامعات وزارة التربية والتعليم كما في ملحق رقم (1) وبناء على اقتراحاتهم تم اعتمادها وصيياغتها،

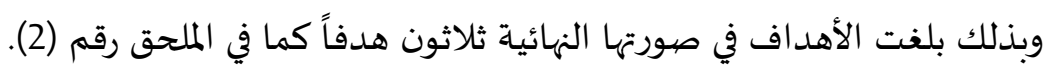
4- ت تحليل جدول مواصفات الاختبار التحصيلي:

يعتبر جدول مواصفات الاختبار أفضل الطرق التي تمكن الاستدلال من خلالهارلها موليات على مواصفات الاختبار

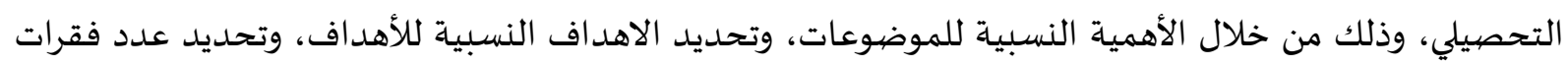

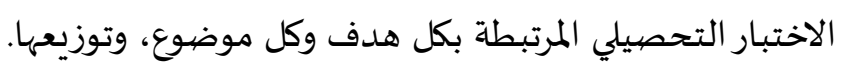

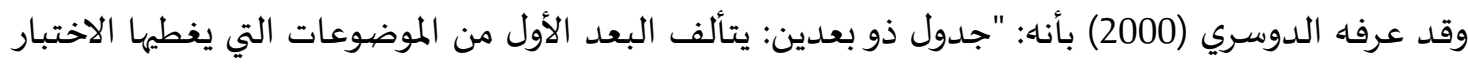

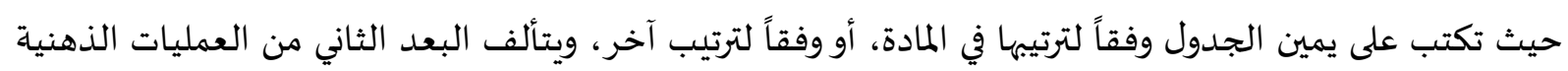

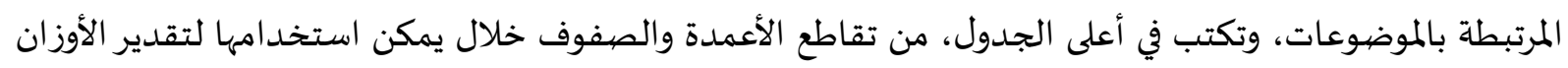
الخاصة بكل موضيوع وعمليه ذهنية" ص 180. وقد قام الباحث ببناء جدول مواصفات الاختبار التحصيلي اعتماد ما ورد في الدوسري ذهنة (2000)، متبعاً الخطوات التالية:

$$
\text { أ- تحديد الوزن النسبي للموضوعات: }
$$

بعد استشارة أعضاء هيئة التدريس في قسم المناهج وطرق التدريس بكلية التربية جامعة أم القرى تحديد الوزن النسبي لكل موضوع على أساس الوقت المستغرق في تدريسا،، وذلك وفقاً للمعادلات التالية:

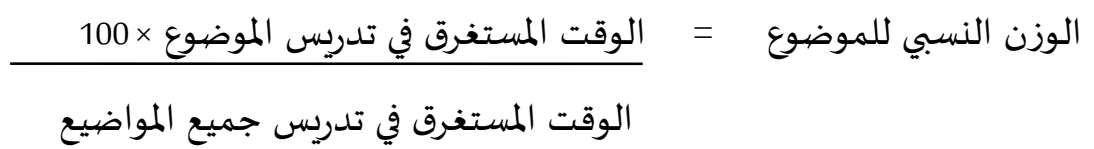


جدول رقم (1) عدد الحصص والوزن النسبي للموضوعات

\begin{tabular}{|c|c|c|}
\hline الوزن النسبي للموضهوع & عدد السـاعات & الموضيوع \\
\hline$\% 40$ & 5 & تقنية المعلومات \\
\hline$\% 33.3$ & 4 & شبكات المعلومات \\
\hline$\% 26.7$ & 3 & الإنترنت مصدراً للمعلومات \\
\hline \%100.00 & 12 & المجموع \\
\hline
\end{tabular}

ويتضح من الجدول رقم (1) المواضيع الخاصة بمقرر مهارات البحث ومصادر المعلومات الذي تم تناولها في

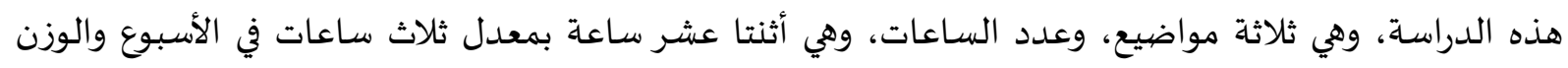

$$
\text { ب- النسبي للمواضيع، وهو 100\% فحديد الأهداف النسبية للأهداف: مجملها. }
$$

قام الباحث بصياغة أهداف سلوكية لتكون منطلقاً لبناء فقرات الاختبار التحصيلي، وفق تصنيف بلوم للأهداف الإجرائية، وذلك لكل موضوع من مواضيع مقرر مهارات البحث ومصادر المعلومات، وكانت الأهداف شاملة

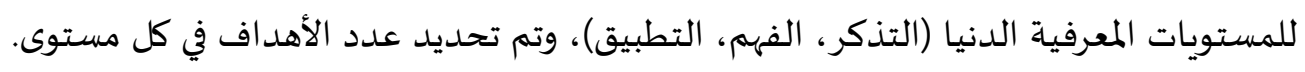
الوزن النسبي للأهداف، وذلك تبعاً للمعادلة التالية:

$$
\text { الوزن النسبي للأهداف في مستوى معين = }
$$

\begin{tabular}{|c|c|c|c|c|}
\hline \multirow{2}{*}{ المجموع - الموع } & \multicolumn{3}{|c|}{ المستويات المعرفية الدنيا للأهداف } & \multirow{2}{*}{ الموضيوع } \\
\hline & التطبيق & الفهم & التذكر & \\
\hline 12 & 3 & 5 & 4 & تقنية المعلومات \\
\hline 10 & 1 & 4 & 5 & شبكات المعلومات \\
\hline 8 & 1 & 5 & 2 & الإنترنت مصدراً للمعلومات \\
\hline 30 & 5 & 14 & 11 & المجموع \\
\hline$\% 100$ & $\% 16.7$ & $\% 46.7$ & $\% 36.7$ & الوزن النسبي لمستويات الأهداف \\
\hline
\end{tabular}

جدول رقم (2) الوزن النسبي للمستويات المعرفية الدنيا

ويوضح الجدول رقم (2) أن المستويات تتركز في المستويات المعرفية الدنيا (التذكر، الفهم، التطبيق)، وخو المون ما تم أخذه في الاعتبار عند إعداد فقرات الاختبار التحصيلي. ج- تحديد نوع مفردات الاختبار التحصيلي:

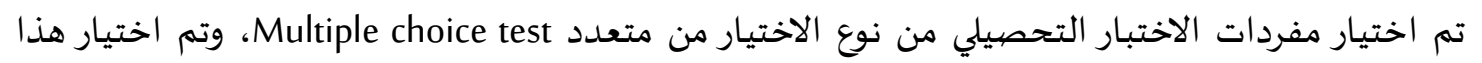

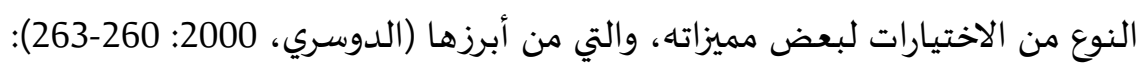
1- - أكثر الانواع شيوعاً. 2- - نسبة التخمين فيه أقل. 3- سهولة التصحيح وسرعته. 4- توفر الموضوعية في تقدير الدرجة. 5- تقيس مستويات متعددة من التعلم. 


$$
\begin{aligned}
& \text { 6- تغطي قدراً كبيراً من المحتوى العلمي. } \\
& \text { 7- يقيس بكفاءة النواتج البسيطة للتعلم. }
\end{aligned}
$$

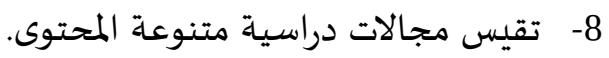

$$
\begin{aligned}
& \text { 9- يستخدم في قياس العديد من مخرجات التعلم. }
\end{aligned}
$$

10- يمكن بتحليل الإجابات تشخيص نواحي القوة والضعف فيد في التحصيل.

\section{تحديد فقرات الاختبار التحصيلي:}

حدد الباحث عدد فقرات الاختبار التحصيلي ب (30) فقرة نظراً لنوع الاختبار ونوع المستويات المعرفية التي

يقيسها، فقد تم توزيعها على المستويات المعرفية العليا، وذلك وفقاً المعادلة التالية:

$$
\text { النسبة المئوية لمستوى الهدف الفرعي × عدد الفقرات الإجمالي }
$$

100

\begin{tabular}{|c|c|}
\hline عدد الفقرات & المستوى الفرعي \\
\hline 11 & التذكر \\
\hline 14 & الفهم \\
\hline 5 & التطبيق \\
\hline 30 & المجموع \\
\hline
\end{tabular}

$$
\text { جدول رقم (3) عدد الفقرات في كل مستوى من المستويات المعرفية }
$$

يوضح الجدول رقم (3) عدد فقرات الاختبار التحصيلي في كل مستوى من المستويات المعرفية الدنيا

(التحليل، التركيب، التقويم).

\begin{tabular}{|c|c|c|c|}
\hline \multicolumn{3}{|c|}{ عدد الفقرات في المستويات المعرفية الدنيا } & \multirow{2}{*}{ الموضهوع } \\
\hline التطبيق & 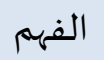 & 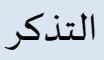 & \\
\hline 3 & 5 & 4 & تقنية المعلومات \\
\hline 1 & 4 & 5 & شبكات المعلومات \\
\hline 1 & 5 & 2 & الإنترنت مصدراً للمعلومات \\
\hline 5 & 14 & 11 & المجموع \\
\hline
\end{tabular}

وقد تم توزيع فقرات الاختبار التحصيلي على كل موضوع، وذلك وفقاً للمعادلة التالية:

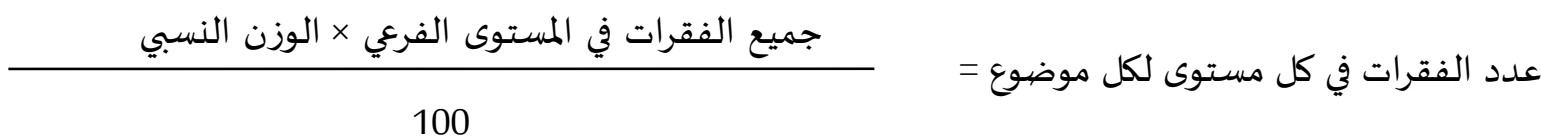

جدول رقم (4) عدد الفقرات في كل مستوى معرفي في موضوع

ويتضح من الجدول رقم (4) عدد فقرات الاختبار التحصيلي في كل مستوى من المستويات المعرفية الدنيا

$$
\text { (التحليل، التركيب، التقويم) على كل موضيوع. }
$$

وقد روعي أثناء صياغة فقرات الاختبار التحصيلي أن تكون الفقرات بسيطة وقصيرة ومفهومانة، وواضحة

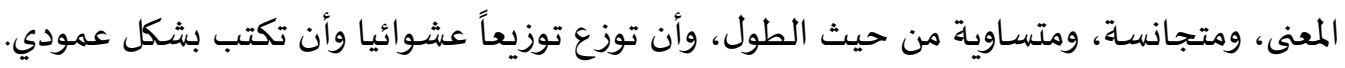


كما تمت مراعاة صياغة البدائل المحتملة وأن تكون واضحة ومتجانسة، ومختصرة، وتحمل إجابة صحيحة

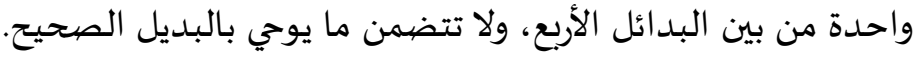

جدول رقم (5) مواصفات الاختبار التحصيلي بصهورته النهائية التهيل

\begin{tabular}{|c|c|c|c|c|c|}
\hline \multirow{2}{*}{ للموضيوعات النسبي } & \multirow{2}{*}{ فتمرات } & \multicolumn{3}{|c|}{ عدد الفقرات في المستويات المعرفية } & \multirow{2}{*}{ 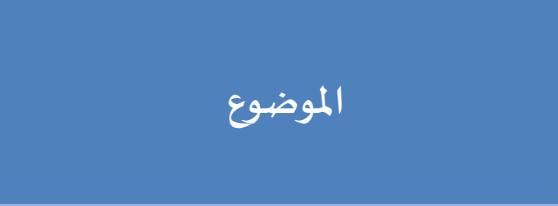 } \\
\hline & & التطبيق & الفهم & التذكر & \\
\hline$\% 40$ & 12 & 3 & 5 & 4 & تقنية المعلومات \\
\hline$\% 33.3$ & 10 & 1 & 4 & 5 & 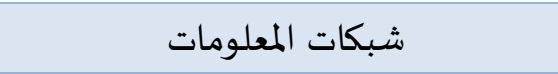 \\
\hline$\% 26.7$ & 8 & 1 & 5 & 2 & الإنترنت مصدراً للمعلومات \\
\hline \multirow{2}{*}{$\% 100.0$} & 30 & 5 & 14 & 11 & 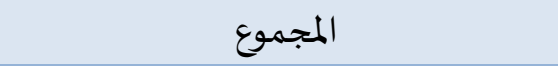 \\
\hline & - & $\% 16.7$ & $\% 46.7$ & $\% 36.7$ & الوزن النسبي للمستويات المعرفية العليا \\
\hline
\end{tabular}

صدق الاختبار التحصيلي:

"يعد الاختبار صادقاً إذا كان يقيس ما أعد لقياسـ فقط "العساف، 2006: 429) ولقياس ذلك استخدم الباحث صدق المحكمين TRUSEES VALIDITY، فقد قام الباحث بعرض الصهورة الأولية للاختبار التحصيلي على سعادة المشرف، وعلى مجموعة من المحكمين من ذوي الاختصاص من اساتذة الجامعات وموجهين ومعلمي مهارات

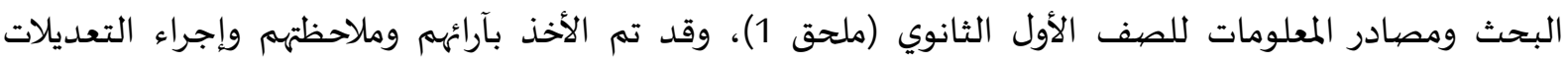

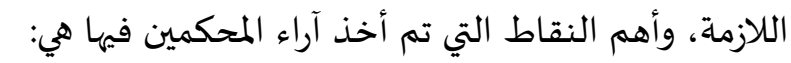

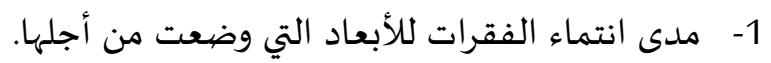
2- - مدى السلامة اللغوية. 3- مدى الصحة العلمية.

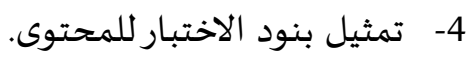
5- إمكانية الحذف والإضيافة.

وقد رأي المحكمون أن الاختبار ملائم وأنه على درجة عالية من الصدل الإق لكن مع إضافة بعد التعديلات في صياغة الأسئلة وبدائلها (انظر الملحق 2).

ثبات الاختبار التحصيلي: يعرف الثبات - كما تقدم - بأنه درجة الاستقرار أو الاتساق في الدرجات المتحققة على أداة القياس مع

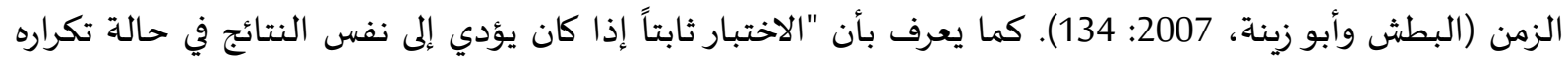

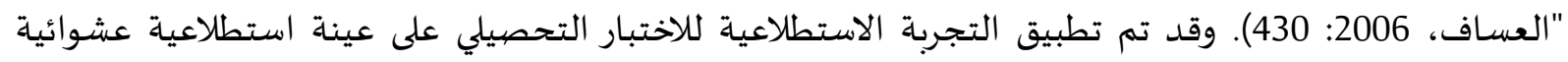

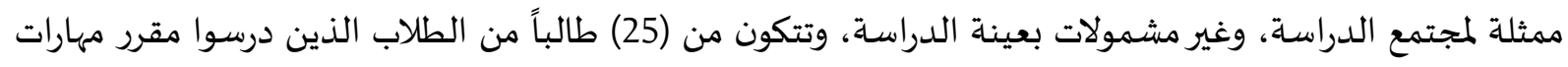

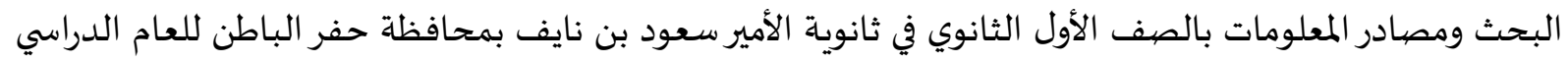

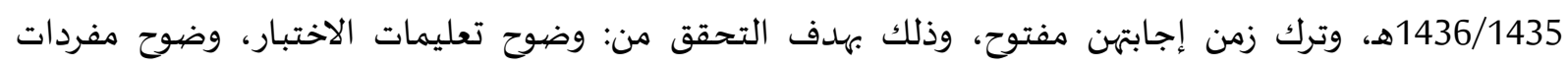
الاختبار، الزمن المناسب للاستجابة على فقرات الاختبار 
واتضح أن ثبات الاختبار التحصيلي يساوي (0.51)، بعد حساباه باستخدام معامل كرونباخ ألفا ( ALPHA

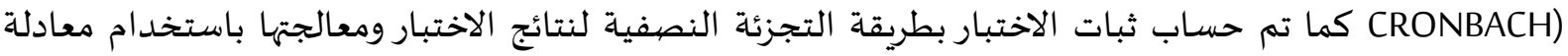

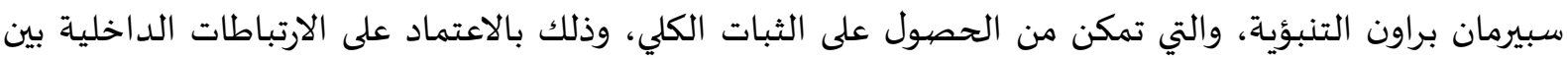

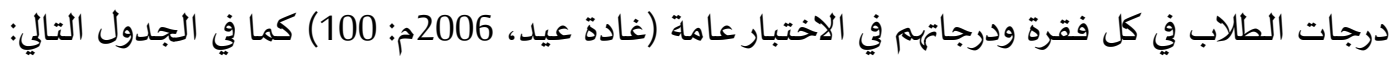
جدول رقم (5) قيم معامل الثبات من خلال التجزئة النصفية

\begin{tabular}{|c|c|c|c|c|c|}
\hline \multicolumn{3}{|c|}{ التجزئة|لنصيفية } & \multirow{2}{*}{ الجزء الثاني } & \multirow{2}{*}{ الجزء الأول } & \multirow{2}{*}{ العدد الكلي } \\
\hline جتمان & سبيرمان براون & ارتباط الجزأين & & & \\
\hline 0.827 & 0.839 & 0.839 & 15 & 15 & 30 \\
\hline
\end{tabular}

يتضح من جدول رقم (5) أن قيم معامل الثبات من خلال التجزئة النصفية التي أظهرت قيم (ارتباط

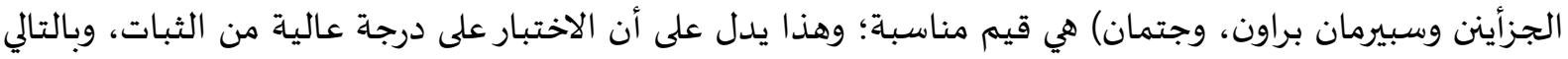

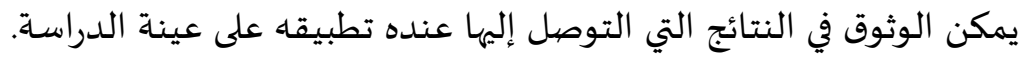

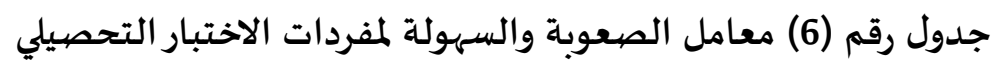

\begin{tabular}{|c|c|c|c|c|c|c|c|c|}
\hline الصعاملة & السهولة & السؤال & الصعامل & السعهولة & السؤال & الصعامل & السهولة & رقمؤم \\
\hline 0.44 & 0.56 & 21 & 0.28 & 0.72 & 11 & 0.36 & 0.64 & 1 \\
\hline 0.36 & 0.64 & 22 & 0.28 & 0.72 & 12 & 0.48 & 0.52 & 2 \\
\hline 0.48 & 0.52 & 23 & 0.2 & 0.8 & 13 & 0.32 & 0.68 & 3 \\
\hline 0.4 & 0.6 & 24 & 0.24 & 0.76 & 14 & 0.4 & 0.6 & 4 \\
\hline 0.36 & 0.64 & 25 & 0.36 & 0.64 & 15 & 0.44 & 0.56 & 5 \\
\hline 0.28 & 0.72 & 26 & 0.28 & 0.72 & 16 & 0.48 & 0.52 & 6 \\
\hline 0.32 & 0.68 & 27 & 0.68 & 0.32 & 17 & 0.44 & 0.56 & 7 \\
\hline 0.44 & 0.56 & 28 & 0.32 & 0.68 & 18 & 0.36 & 0.64 & 8 \\
\hline 0.4 & 0.6 & 29 & 0.44 & 0.56 & 19 & 0.48 & 0.52 & 9 \\
\hline 0.52 & 0.48 & 30 & 0.48 & 0.52 & 20 & 0.4 & 0.6 & 10 \\
\hline
\end{tabular}

يلاحظ من خلال الجدول رقم (6) أن قيم معامل السهولة لمفردات الاختبار التحصيلي تراوحت بين (0.32

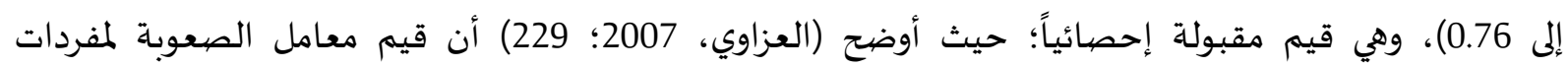

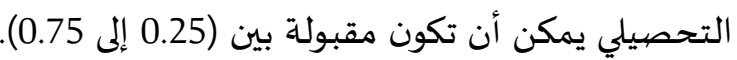

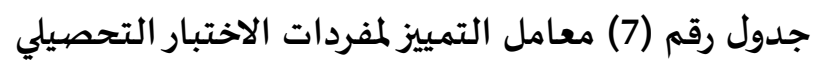

\begin{tabular}{|c|c|c|c|c|c|}
\hline معامل التمييز & رقم السؤال & معامل التمييز & رقم السؤال & معامل التمييز & رقم السؤال \\
\hline 0.42 & 21 & 0.50 & 11 & 0.33 & 1 \\
\hline 0.67 & 22 & 0.42 & 12 & 0.33 & 2 \\
\hline 0.50 & 23 & 0.42 & 13 & 0.42 & 3 \\
\hline 0.33 & 24 & 0.58 & 14 & 0.50 & 4 \\
\hline 0.42 & 25 & 0.42 & 15 & 0.33 & 5 \\
\hline
\end{tabular}


المجلة العربية للعلوم ونشر الأبحاث ـ مجلة العلوم التريوية والنفسية ـ المجلا الخامس ـ العدد الخامس و العثرون ـ يوليو 2021م

\begin{tabular}{|c|c|c|c|c|c|}
\hline معامل التمييز & رقم السيؤال & معامل التمييز & رقم السؤال & معامل التمييز & رقم السيؤال \\
\hline 0.75 & 26 & 0.75 & 16 & 0.58 & 6 \\
\hline 0.58 & 27 & 0.42 & 17 & 0.42 & 7 \\
\hline 0.42 & 28 & 0.33 & 18 & 0.67 & 8 \\
\hline 0.33 & 29 & 0.58 & 19 & 0.75 & 9 \\
\hline 0.33 & 30 & 0.67 & 20 & 0.67 & 10 \\
\hline
\end{tabular}

اتضح من الجدول رقم (7) أن قيم معامل التمييز لأسئلة الاختبار التحصيلي مقبولة؛ حيث تنحصر بين

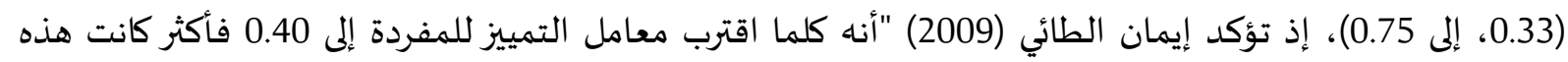

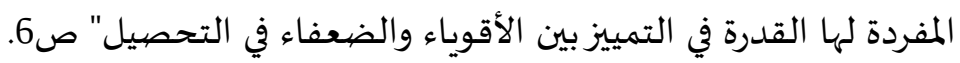

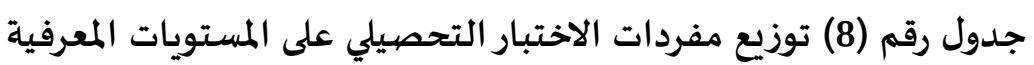

\begin{tabular}{|c|c|c|}
\hline أرقام المفردات & 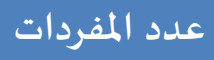 & المستوى المعرفي \\
\hline $24-23-16-15-14-13-4-3-2-1$ & 11 & 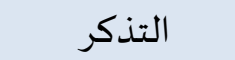 \\
\hline $30-29-28-27-25-21-20-19-18-9-8-7-6-5$ & 14 & 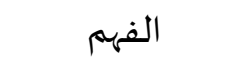 \\
\hline $26-22-12-11-10$ & 5 & 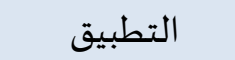 \\
\hline
\end{tabular}

إعداد دليل المتعلم والمعلم لاستخدام تويتر: تم إعداد دليل مصغر كما في ملحق رقم (4) من أجل شرح طريقة التسجيل في تويتر، ومن أجل متابعة

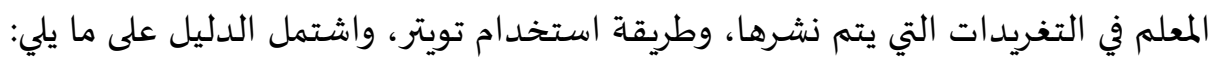

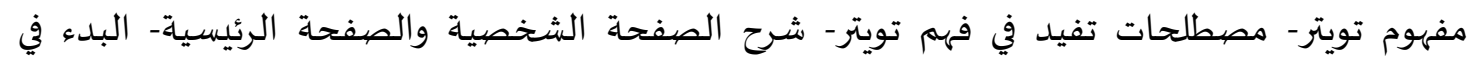
استخدام تويتر. تلميحات حول الهاش تاق- فوائد الهاش تاق- بعض الأفكار التي تساعد لاستخدام الهاش تاق في التعليمكيفية توظيف تويتر في التعليم

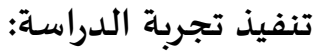

اتبع الباحث مجموعة من الخطوات المتتابعة لتطبيق تجربة الدراسة وهي:

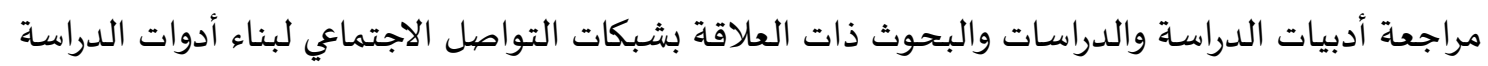
وتدعيم الإطار النظري. إعداد دليل المعلم والمتعلم لاستخدام تويتر في تدريس مقرر مهارات البحث ومصادر المعلومات للصف الأول الثانوي. ملحق رقم (5و6).

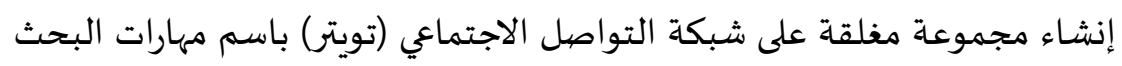

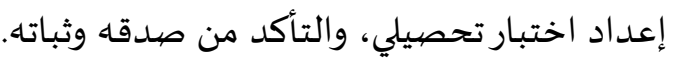

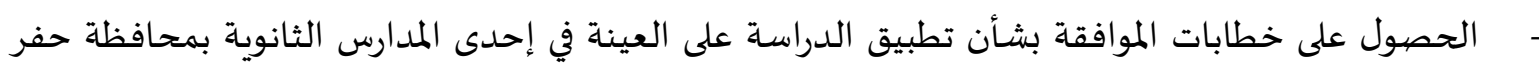
الباطن كما في ملحق رقم (7و8). 
- ـ اختيار عينة عشوائية مكونة من مجموعتين ضابطة وتجريبية ثم التأكد من تكافؤهما في العمر الزمني

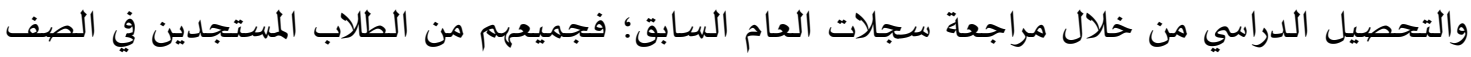
الأول الثانوي ولا يوجد بينهم طالب بالي للإعادة. تطبيق الاختبار التحصيلي القبلي على المجموعتين الضابطة والتجريبية، وتم تطبيق الاختبار في المدرسة

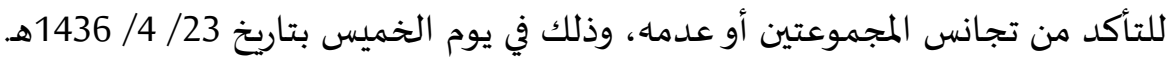

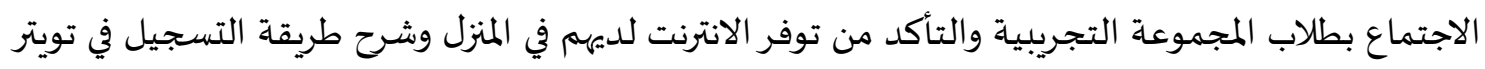

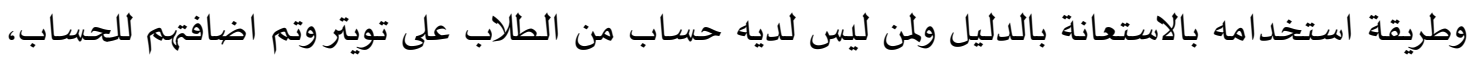

$$
\text { وتم تدريهه داخل معمل الحاسب الالي بالمدرسة. }
$$

تزويد طلاب المجموعة التجريبية بدليل المتعلم لاستخدام تويتر؛ وهو دليل مختصر يوضح طاديل طريقة التسجيل

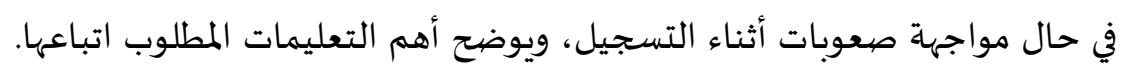

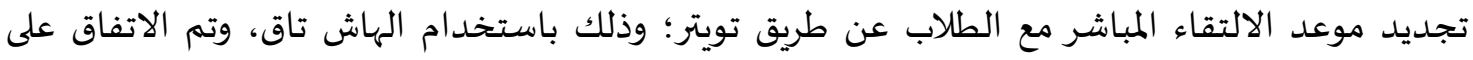

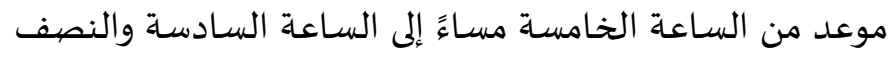

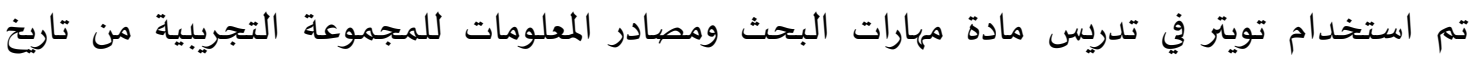

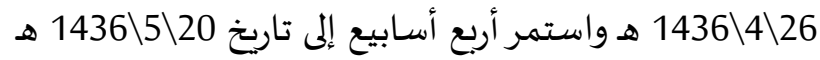
تطبيق الاختبار التحصيلي البعدي، بعد الانتهاء من تدريس المجموعة الضابطة بالطريقة الاعتيادية

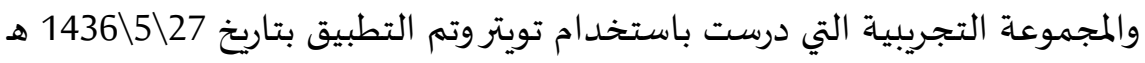

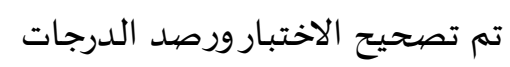

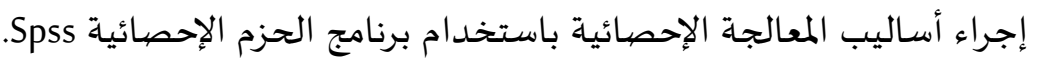

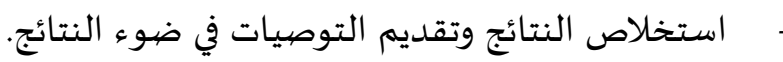

التحقق من تكافؤ عينة البحث:

تم استخدام القياس القبلي للمجموعتين الضابطة والتجريبية في القياس القبلي قبل البداء التجربة بإجراء

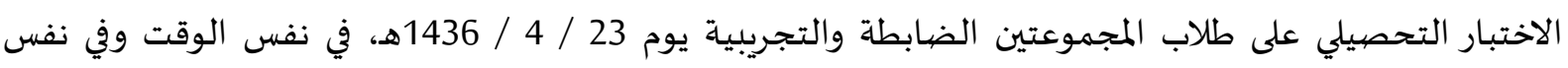
الظروف، وتم حساب قيمة (ت) للتعرف على مستوى الدلالة الإحصائية قيمة (ت) للفرق بين متوسطي طلاب الماب

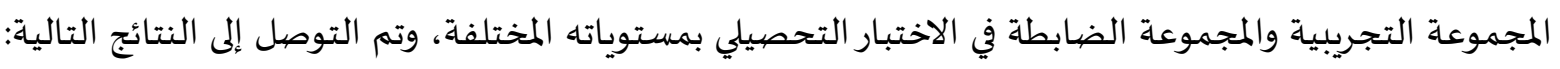

\begin{tabular}{|c|c|c|c|c|c|c|c|}
\hline مستوى الدلالة & قيمة ت & الحربة & الانحراف & المتوسط الحسابي & علداد & المجموعات & المسيتويات المعرفية \\
\hline \multirow{2}{*}{0.704} & \multirow{2}{*}{0.382} & \multirow{2}{*}{48} & 2.03 & 5.88 & 25 & الضـابطة & \multirow{2}{*}{ مستوى التذكر } \\
\hline & & & 1.66 & 6.08 & 25 & التجريبية & \\
\hline \multirow{2}{*}{0.681} & \multirow{2}{*}{0.414} & \multirow{2}{*}{48} & 2.84 & 8.20 & 25 & الضـابطة & \multirow{2}{*}{ مستوى الفهم } \\
\hline & & & 1.83 & 8.48 & 25 & التجريبية & \\
\hline \multirow{2}{*}{0.806} & \multirow{2}{*}{0.247} & \multirow{2}{*}{48} & 0.65 & 1.40 & 25 & الضـابطة & \multirow{2}{*}{ مستوى التطبيق } \\
\hline & & & 0.49 & 1.36 & 25 & التجريبية & \\
\hline
\end{tabular}
جدول رقم (9) نتائج اختبار" ت: Independent Samples Test" الفروق بين متوسطي درجات المجموعة الضـابطة والتجريبية في التطبيق القبلي للاختبار التحصيلي بمستوياته المختلفة 
المجلة العربية للطوم ونشر الأبحاث ـ مجلة العلوم التريوية والنفسية ـ المجلا الخامس ـ العدد الخامس والعثرون ـ يوليو 2021م

\begin{tabular}{|c|c|c|c|c|c|c|c|}
\hline مستوى الدلالة & قيمة ت & الحرية درجة & الانتحراف & المتوسط الحسابي & علدد & المججموعات & المستويات المعرفية \\
\hline \multirow{2}{*}{0.723} & \multirow{2}{*}{0.356} & \multirow{2}{*}{48} & 5.06 & 15.48 & 25 & الضابطة & \multirow{2}{*}{ مجمل القياس القبلي للاختبار } \\
\hline & & & 3.55 & 15.92 & 25 & التجريبية & \\
\hline
\end{tabular}

يوضح الجدول رقم (9) نتائج اختبار "ت" لمتوسطي درجات طلاب المجموعة الضابطة والمجموعة التجريبية

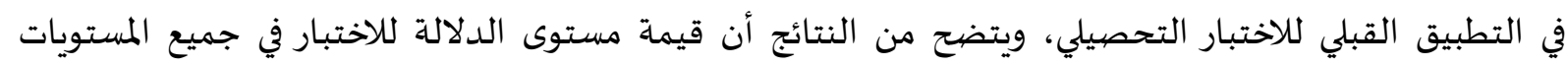

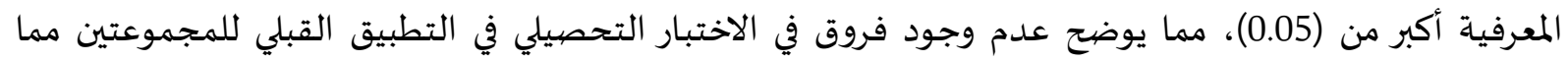

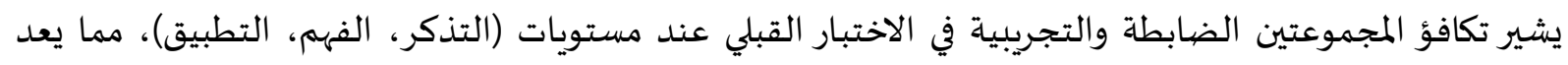

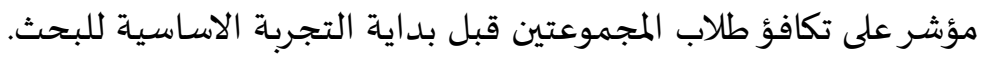

$$
\text { الأسساليب الإحصائية }
$$

تم استخدام برنامج الحزم الإحصائية الخاص بالعلوم الاجتماعية (Spss)، في تحليل البيانات الكمية

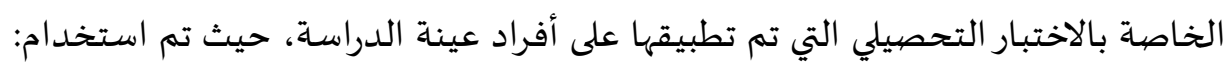
1- التجزئة النصفية باستخدام معامل سبيرمان براون لحساب ثبات التبات الاختبار التحصيلي.

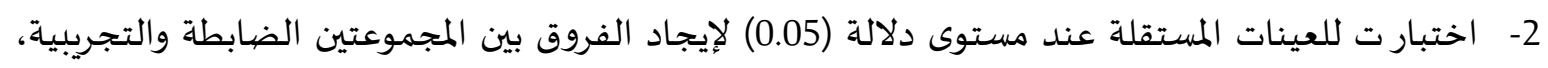

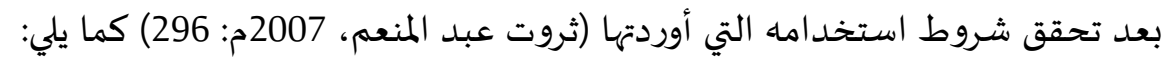

$$
\text { • أن تكون العينتان مستقلتين وعشوائيتين. }
$$

هأن يكون المتغير معتدلاً (طبيعياً)، ويمكن التغاضي عن هذئ لمدا الشرط إذا كان حجم العينة كبير (اكبر من

$$
\text { تجانس التباين. }
$$

3- مربع إيتا Eta Squaredلقياس حجم تأثير المتغير التجريبي على المجموعة التجريبية، فقد ذكرت جولي بالانت

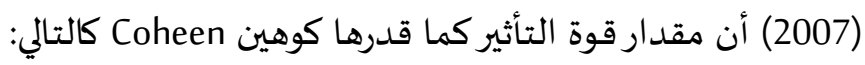

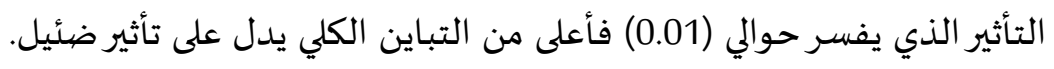

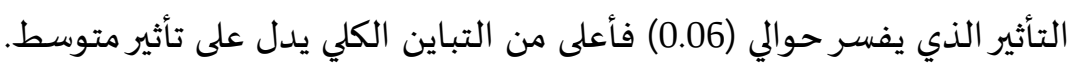

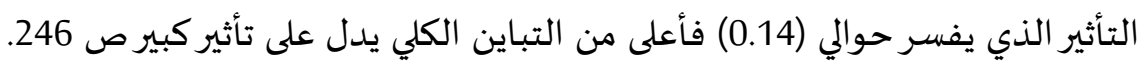

4- قيمة d للدلالة على حجم التأثير، وتفسر حسب تقدير كوهين Coheen كما ذكر الشمراني، 2012م: 22) على كلى

$$
\text { النحو التالي: قaمة }
$$

$$
\begin{aligned}
& \text { قيمة (d) = } 0.2 \text { حجم التأثير صغير. } \\
& \text { قيمة (d) = } 0.5 \text { حجم التأثير متوسط. } \\
& \text { قيمة (d) = } 0.8 \text { حجم التأثير كبير. }
\end{aligned}
$$


4- عرض نتائج الدراسة ومناقشتها. نتيجة السؤال الأول: "هل توجد فروق ذات دلالة إحصائية عند مستوى دلالة (0.05) في متوسط تحصيل الطلاب في مقرر مهارات البحث ومصادر المعلومات للصف الأول الثانوي بمحافظة حفر الباطن بين المجموعتين التجريبية والضابطة عند المستوى المعرفي الأول في تصنيف بلومارو المعات (التذكر)؟ وللتعرف على الفروق في متوسطات تحصيل طلاب مقرر مهارات البحث ومصادر المعلومات للصف الأول

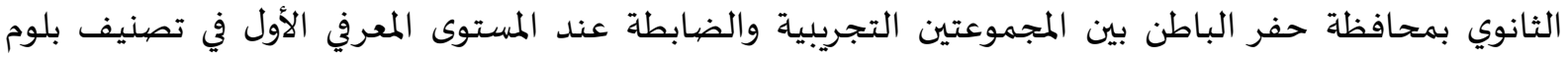

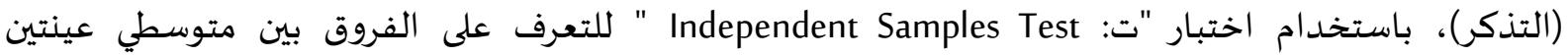

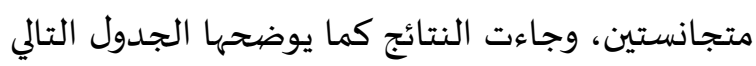
جدول رقم (10) نتائج اختبار" ت: Independent Samples Test" الفروق بين متوسط تحصيل التيل الطلاب في مقرر

مهارات البحث ومصدادر المعلومات للصف الأول الثانوي بمحافظة حفر الباطن بين المجموعتين التجريبية

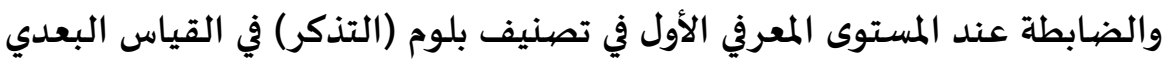

\begin{tabular}{|c|c|c|c|c|c|c|c|}
\hline مستوى الدلالة & قيمة ت ت & الحرية & الانحراف & المتوسط الحسابي & علطداب & المجموعات & المستويات المعرفية \\
\hline \multirow{2}{*}{$* * 0.000$} & \multirow{2}{*}{5.287} & \multirow{2}{*}{48} & 1.55 & 6.08 & 25 & الضـابطة & \multirow{2}{*}{ مستوى التذكر } \\
\hline & & & 1.76 & 8.56 & 25 & التجريبية & \\
\hline
\end{tabular}

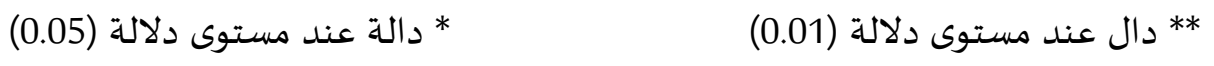

يوضح الجدول رقم (10) نتائج اختبار "ت" لمتوسطي درجات طلاب المجموعة الضابطة والمجمموعة التجريبية في القياس البعدي للاختبار التحصيلي بعد تطبيق التجربة على المجموعة التجريبية وهي التي استخدمت ( تويتر)في دراسة الوحدة الأولى من مقرر مهارات البحث ومصادر المعلومات في المستوى المعرفي (التذكر) ويتضح من النتائج أن قيمة مستوى الدلالة أقل من (0.01)، مما يشير إلى وجود فروق في في متوسطات الدات الاختبار بين المجموعة الضابطة والمجموعة التجريبية التي درست باستخدام تويتر لصالح المجموعة التجريبية بمتوسط (8.56)، مما يعني تأثير استخدام شبكة التواصل الاجتماعي (تويتر) في التدريس عند المستوى المعرفي (التذكر). نتيجة السؤال الثاني: هل توجد فروق ذات دلالة إحصائية عند مستوى دلالة (0.05) في متوسط تحصيل الطلاب في مقرر مهارات البحث ومصادر المعلومات للصف الأول الثانوي بمحافظة حفر الباطن بين المجنموعتين

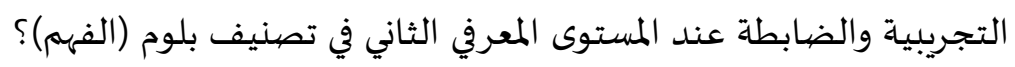

للتعرف على الفروق في متوسطات تحصيل طلاب مقرر مهارات البحث ومصادر المعلومات للصف الأول

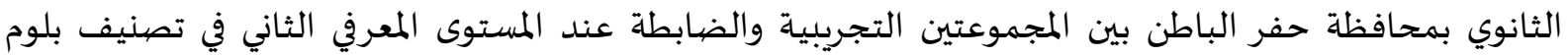
(الفهه)، باستخدام اختبار "ت: Independent Samples Test " للتعرف على الفروق بين متوسطي عينتين

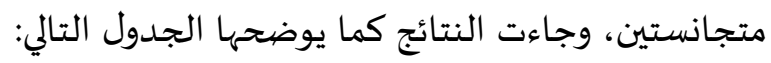
جدول رقم (11) نتائج اختبار" ت: Independent Samples Test" الفروق بين متوسط تحصيل الطلاب في مقرر مهارات البحث ومصيادر المعلومات للصف الأول الثانوي بمحافظة حفر الباطن بين المجموعتين التجريبية

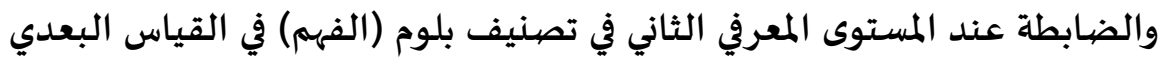

\begin{tabular}{|c|c|c|c|c|c|c|c|}
\hline مستوى الدلالة & قيمة ت & الحربة & الالنعراف & المتوسط الحسب & الطلاب & المجموعات & المستويات المعرفية \\
\hline \multirow{2}{*}{$* * 0.000$} & \multirow{2}{*}{4.686} & \multirow{2}{*}{48} & 1.98 & 8.36 & 25 & الضيابطة & \multirow{2}{*}{ مستوى الفهم } \\
\hline & & & 1.95 & 10.96 & 25 & التجريبية & \\
\hline
\end{tabular}




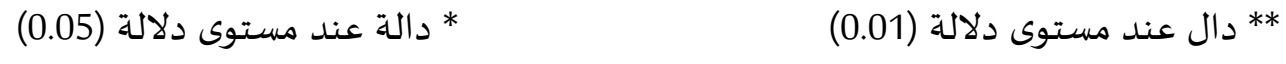

يوضح الجدول رقم (11) نتائج اختبار "ت" لمتوسطي درجات طلاب المجموعة الضابطة والمجموعة التجريبية

في القياس البعدي للاختبار التحصيلي بعد تطبيق التجربة على المجموعة التجريبية وهي التي استخدمت ( تويتر) في

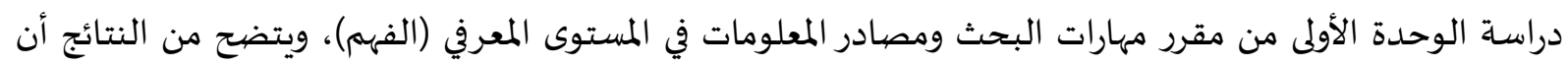
قيمة مستوى الدلالة أقل من (0.01)، مما يشير إلى وجود فروق في متوسطات الإختبار بين المجمدوعة الضاديابطة

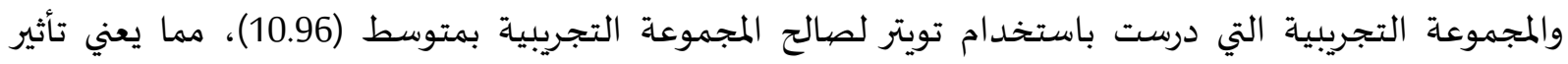

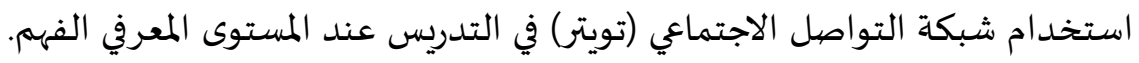
نتيجة السؤال الثالث: هل توجد فروق ذات دلالة إحصائية عند مستوى دلالة (0.05) في متوسط تحصيل

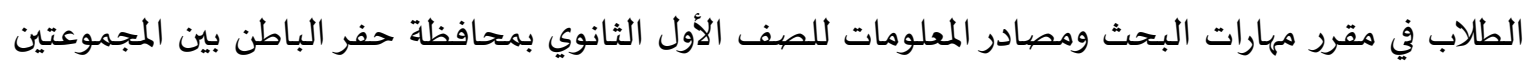

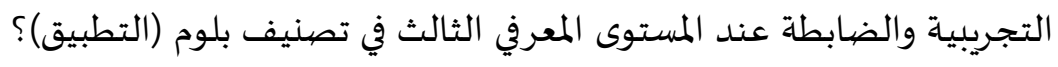

للتعرف على الفروق في متوسطات تحصيل طلاب مقرر مهارات البحث ومصادر المعلومات للصف المأول

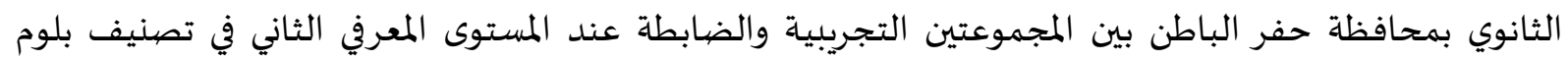
(التطبيق)، باستخدام اختبار "ت: Independent Samples Test " للتعرف على الفروق بين متوسطي عينتين

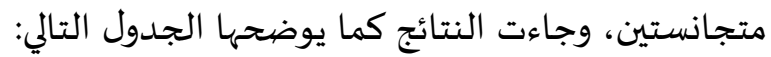
جدول رقم (12) نتائج اختبار" ت: Independent Samples Test" الفروق بين متوسط تحصيل الطلاب في مقرر مهارات البحث ومصادر المعلومات للصف الأول الثانوي بمحافظة حفر الباطن بين المجموعتين التجريبية

\begin{tabular}{|c|c|c|c|c|c|c|c|}
\hline مستوى الدلالة & قيمة ت & درجة الحربة & الانحراف & المتوسط الحسبابي & علطلاب & المجموعات & المستويات المعرفية \\
\hline \multirow{2}{*}{$* * 0.000$} & \multirow{2}{*}{8.250} & \multirow{2}{*}{48} & 0.48 & 1.68 & 25 & الضابطة & \multirow{2}{*}{ مستوى التطبيق } \\
\hline & & & 0.70 & 3.08 & 25 & التجريبية & \\
\hline
\end{tabular}

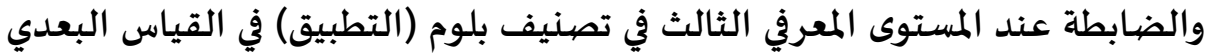

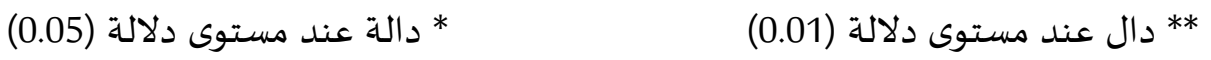

يوضيح الجدول رقم (12) نتائج اختبار "ت" لمتوسطي درجات طلاب المجموعة الضابطة والمجموعة التجريبية

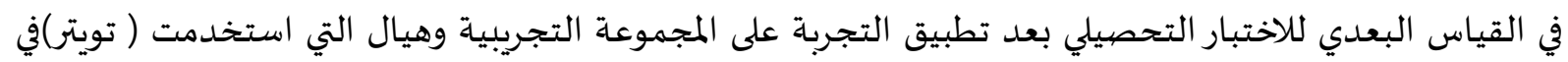

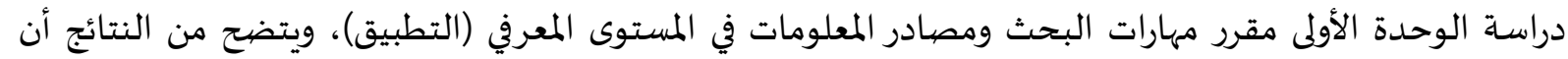
قيمة مستوى الدلالة أقل من (0.01)، مما يشير إلى وجود فروق في متوسطات الاختبار بين المجموعة الضابطة

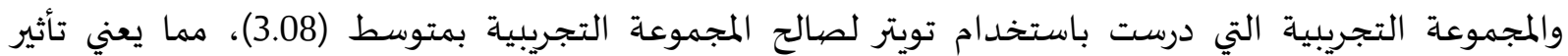

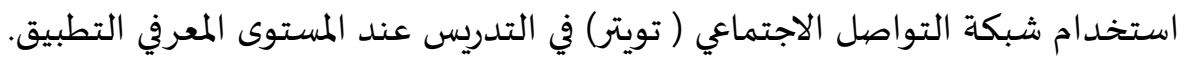
نتيجة السؤال الرابع: هل توجد فروق ذات دلالة إحصائية عند مستوى دلالة (0.05) في متوسط تحصيل

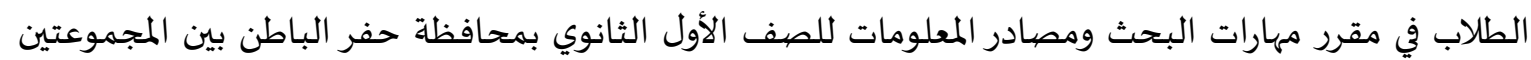

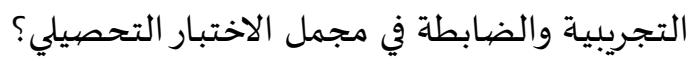
وللتعرف على الفروق في متوسطات تحصيل طلاب مقرر مهارات البحث ومصيادر المعلومات للصف فهل الأول الثانوي بمحافظة حفر الباطن بين المجموعتين التجريبية والضابطة في القياس البعدي، في مجمل الاختبار التحصيلي مباري باستخدام اختبار "ت: Independent Samples Test " للتعرف على الفروق بين متوسطي عينتين متجانستين، وجاءت

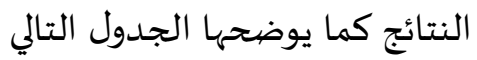


جدول رقم (13) نتائج اختبار" ت: Independent Samples Test" الفروق بين متوسط تحصيل الطلاب في مقرر

مهارات البحث ومصادر المعلومات للصف الأول الثانوي بمحافظة حفر الباطن بين المجموعتين التجريبية والضابطة في القياس البعدي في مجمل الاختبار التحصيلي

\begin{tabular}{|c|c|c|c|c|c|c|}
\hline مستوى الدلالة & قيمة ت & درجة الحرية & الاندراف & المتوسيط & عدد الطلاب & المجموعات \\
\hline \multirow{2}{*}{$* * 0.000$} & \multirow{2}{*}{6.075} & \multirow{2}{*}{48} & 3.50 & 16.12 & 25 & الضابطة \\
\hline & & & 4.02 & 22.60 & 25 & التجريبية \\
\hline
\end{tabular}
* دالة عند مستوى دلالة (0.05)
(0.01) (2*) دال عند مستوى دلالة

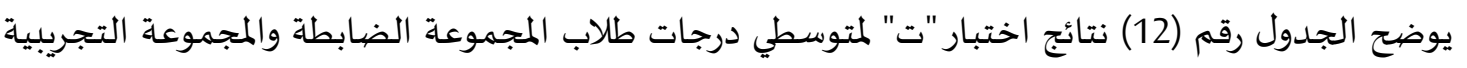

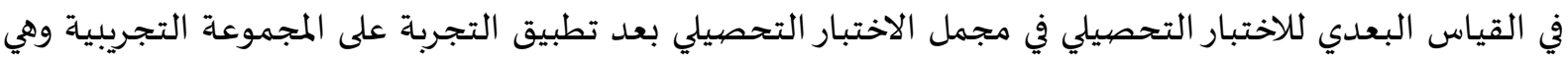

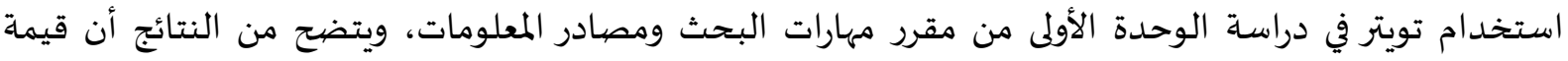

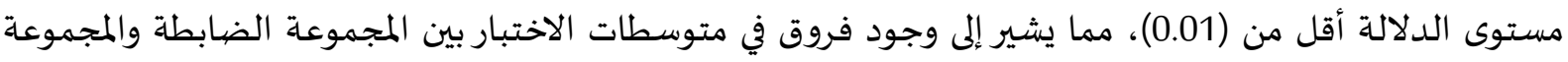

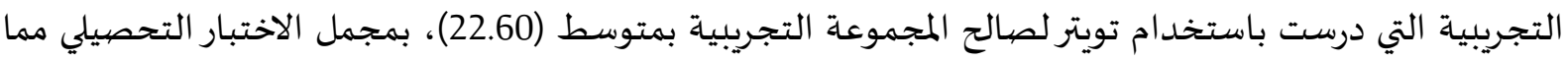

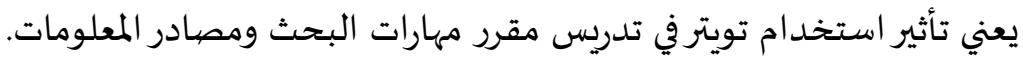

مناقشـة نتائج البحث:

عند المقارنة بين أداء المجموعة الضابطة والمجموعة التجريبية، أظهرت النتائج وجود فروقاً دالة إحصائياً

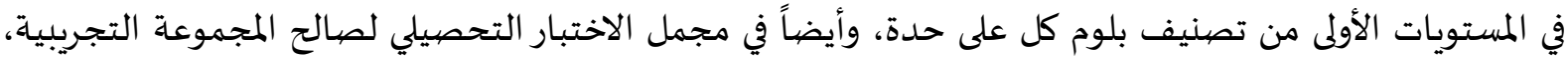

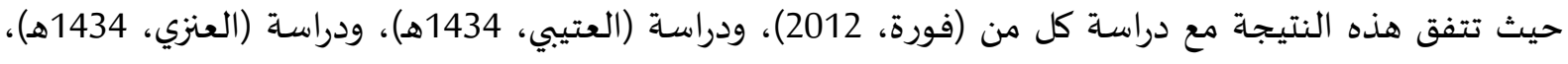

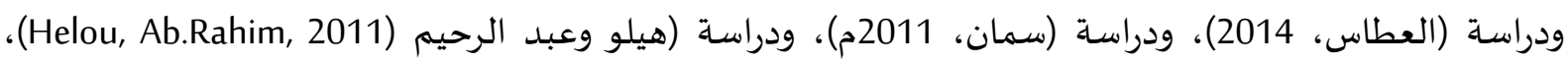
ودراسة (عمر، 1433هـ) التي أشارت إلى أن المجموعة التي تدرس باستخدام شبكات التواصل الاجتماعي تحصيلها

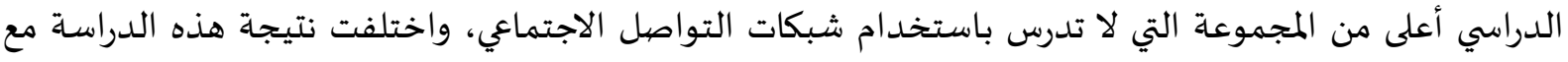

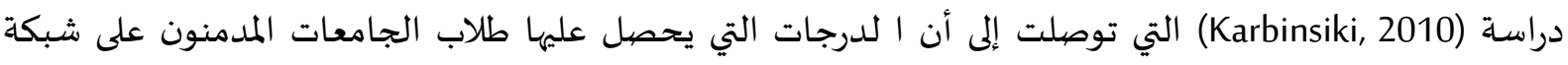

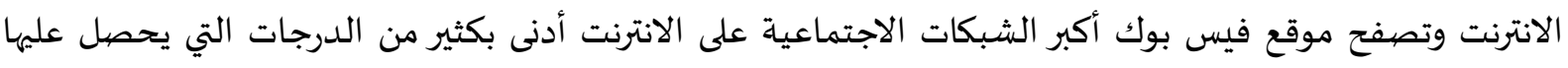

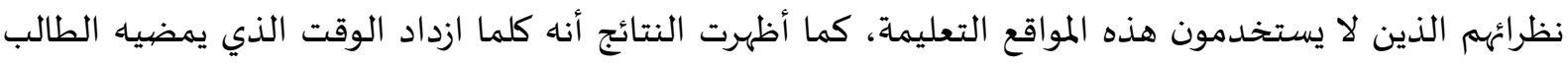

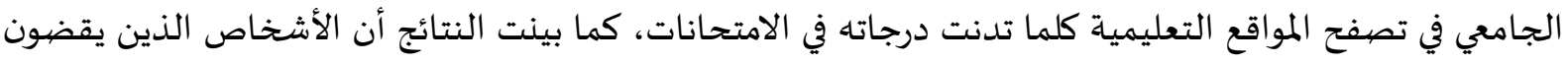

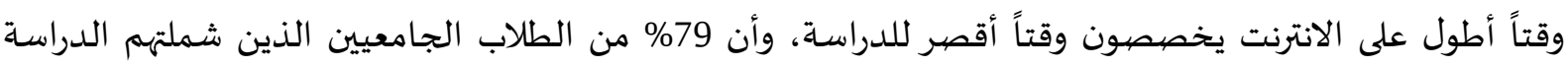

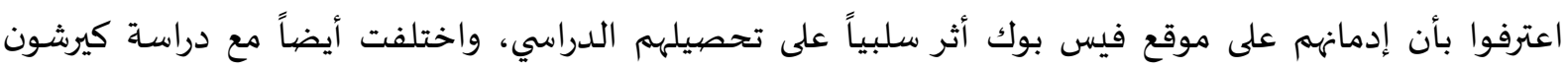

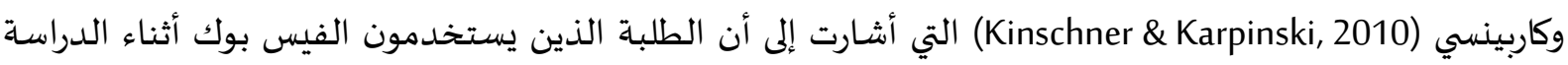

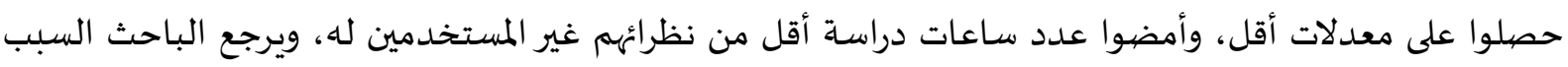

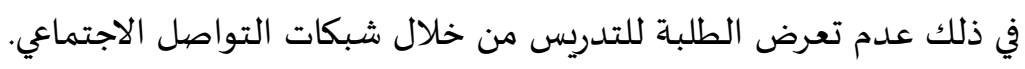

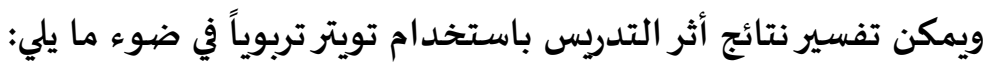

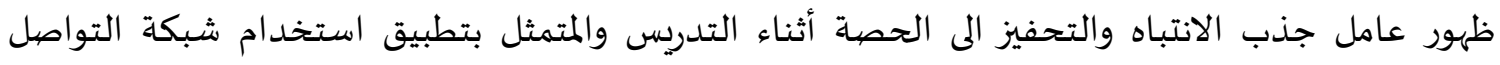
الاجتماعي (تويتر) في تلقي المعلومات وتفسيرها فهما والاحتفاظ بها في الذاكرة واكتساب المهارات والقينيم 
- - التعاون بين المعلم والطلاب خاصة في تبادل الآراء والمناقشة حول الافكار المختلفة التي يطرحها الطلاب. - - اكتساب الطلاب مهارة الحصول على المعلومة، وتنقيحها وتلخيصها.

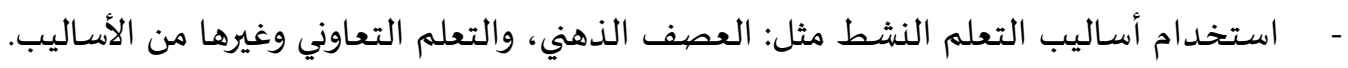

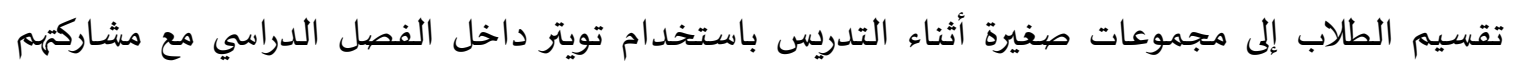

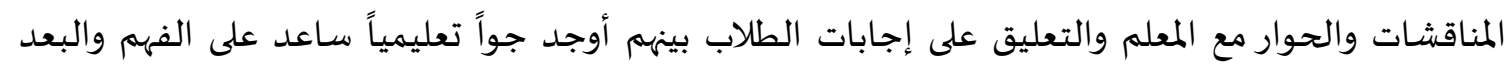
عن الحفظ. حداثة المعلومة المقدمة في المجموعة، وإثراء الحصة الدراسية في التعرف على مصادر معلومات أخرى. تشجيع بعض الطلاب على المشاركة (حيث تحقق هنا عنصر مراعاة الفروق الفردية)

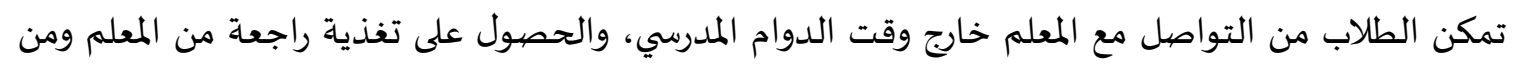
الطلاب فيما بين

خلاصهة نتائج الدراسة. بينت نتائج الدراسة الآتي: 1- توجد فروق ذات دلالة إحصائية عند مستوى دلالة (0.05) في متوسط تحصيل الطلاب في مقرر مهارات

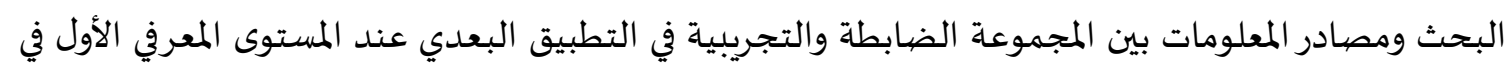

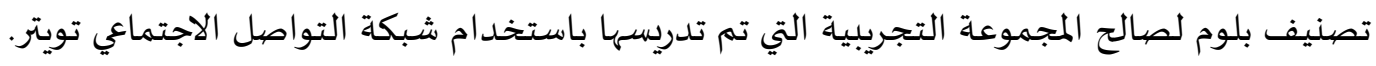
2- توجد فروق ذات دلالة إحصائية عند مستوى دلالة (0.05) في متوسط تحصيل الطلاب في مقرر مهارات

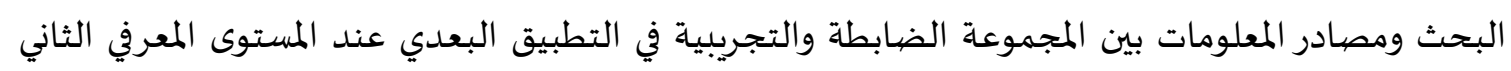
في تصنيف بلوم (الفهم) لصالح المجموعة التجريبية التي تم تدريسها باستخدام تويتر. 3- توجد فروق ذات دلالة إحصائية عند مستوى دلالة (0.05) في متوسط تحصيل الطلاب في مقرر مهارات

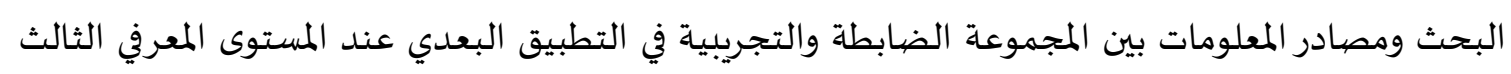
في تصنيف بلوم (التطبيق)لصالح المجموعة التجريبية التي تم تدريسها باستخدام تويتر.

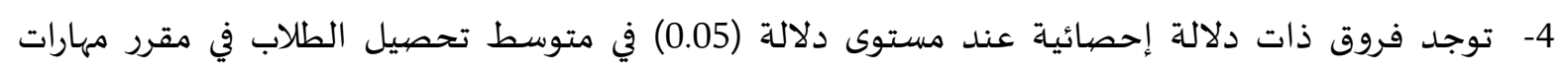

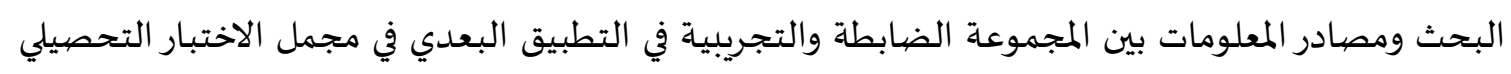

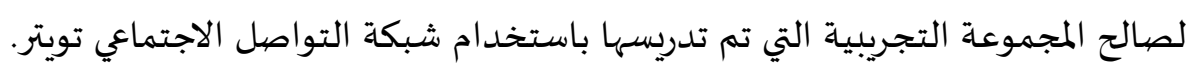

\section{توصيات الدراسة ومقترحاتها.}

1. تفعيل التدريس باستخدام شبكات التواصل الاجتماعي وخصوصا (تويتر) في مقررات مهارات البحث ومصادر المعلومات في جميع الصفوف التعليمية. 2. الاهتمام بالدورات التدربية التأهيلية لمعلهي ومشرفي المرحلة الثانوية، على استخدام شبكات التواصل

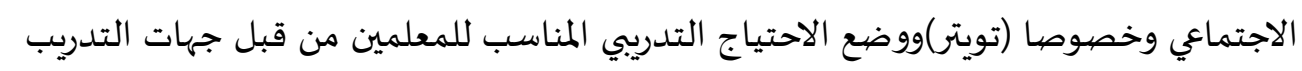

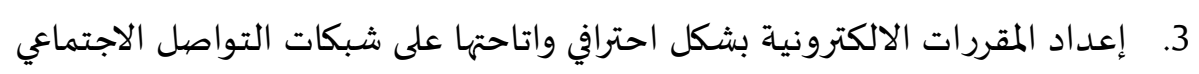

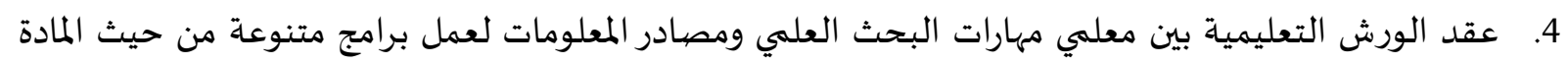

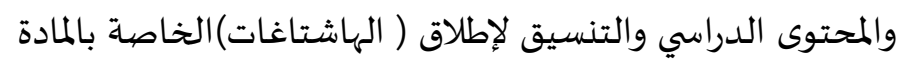

5. انشاء أنشطة تفاعلية باستخدام التطبيقات المتاحة في تويتر. 
6. تطوير الدعم الفني لشبكات معامل الحاسب الالي وصيانتها 7. استخدام شبكات التواصل الاجتماعي كمصادر تعلم تساعد في التواصل بين الطلاب ودعم المقررات الدراسية 8. مما يقترح الباحث إجراء دراسات تكميلية في الموضوعات التوات الآتية:

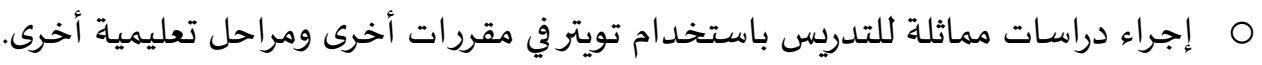
O تقويمية حول العقبات التي تقابل اعتماد شبكات التواصل الاجتماعي ( تويتر) في العملية التعليمية

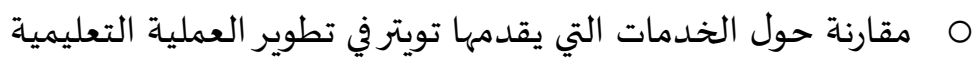
O معوقات استخدام شبكات التواصل الاجتماعي داخل وخارج الفصول الدراسية وإيجاد الحلول المناسبة.

- إبراهيم، محمد عبد الرازق؛ أبو زيد، عبد الباقي عبد المنعم (2007). مهارات البحث التربوي. المملكة الأردنية الهاشمية، عمان، دار الفكر.

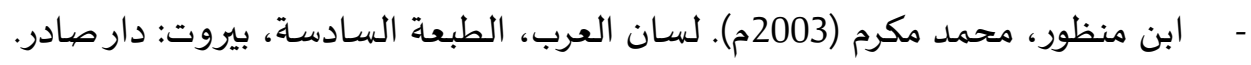

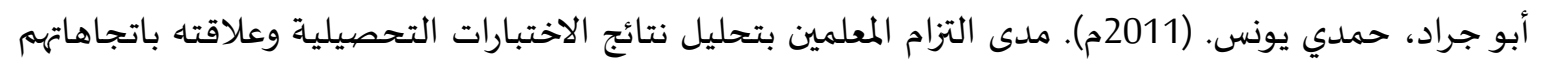

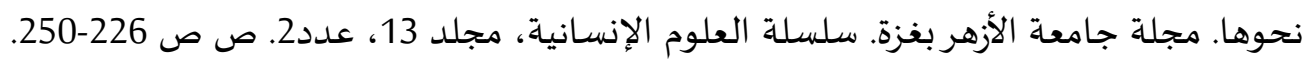

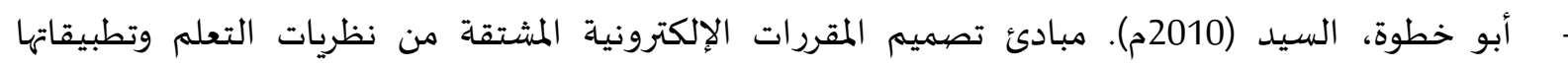
التعليمية. دراسة مقدمة إلى مؤتمر دور التعلم الإلكتروني في تعزيز مجتمعات المعرفة، مركئ، مركز زين للتعلم الإلكتروني، البحرين. - أبو خطوة، السيد عبد المولى، السيد الباز، وأحمد نصبي أنيس الشربيني (2014م). شبكة التواصل الاجتماعي

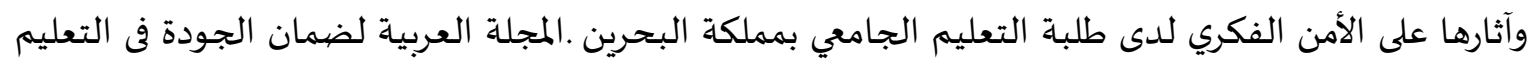

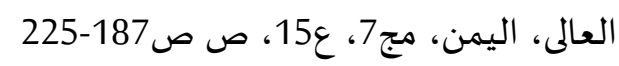
أبو شنب، حمزة اسماعيل (1434 هـ). تقنيات التواصل الاجتماعي.. الاستخدامات والمميزات تم استرجاعه بتاريخ

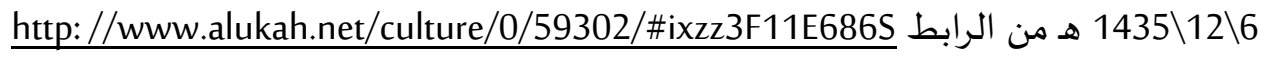
الأحدب ليلى (1424هـ) ألف باء الحب والجنس، ط 1من مكتبات تهامة، مركز الراية، الرياض

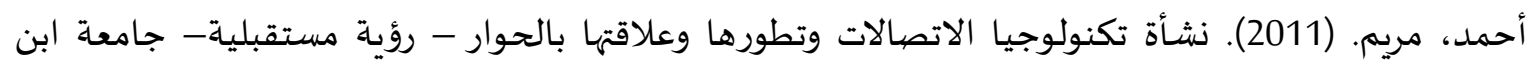
طفيل، المغرب. أرابيان بيزنس (2014م). السعوديون في طليعة مستخدمي وسائل التواصل الاجتماعي. تم استرجاعه من الرابط: هـ بتاريخ http: //goo.gl//ZpyGa أيوب، السيد عيسي (1997): الاستراتيجيات الحديثة ودور المعلم في العملية التربوية، الكويت، مجلة مركز

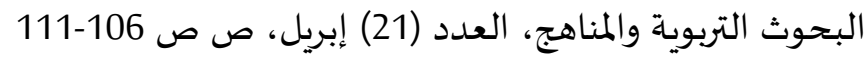
بالانت، جولي. (2007م). التحليل الإحصائي باستخدام برنامج SPss. ترجمة خالد العداد العامري. (ط2). القاهرة: دار الفاروق للنشروالتوزيع. البحر، محمد عبد اللطيف، وصلاح، عبد الفتاح (2006م). مادة المكتبة والبحث بين التنظير، مجلة المعلوماتية،

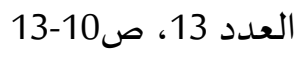


البطش، محمد وليد؛ أبوزينة، فريد كامل. (2007م). مناهج البحث العلمي: تصميم البحث والتحليل الإحصائي.

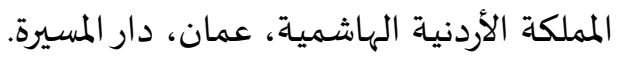

البوابة العربية للأخبار التقنية 2. (2013م). السعودية الأكثر استخداما لتويتر في العالم، تم استرجاعهاء بتاريخ

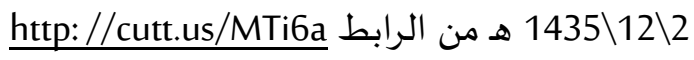

البوابة العربية للأخبار التقنية1. (2013): 70 مليون عربي يستخدمون شبكات التواصل الاجتماعي. تم استرجاعها

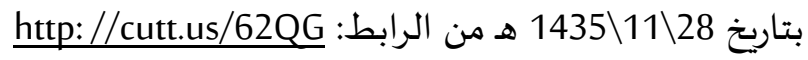
تريكي، حسان (2014م). التهديدات الأمنية المرتبطة بالاستخدامات السيئة لشبكات التواصل الاجتماعي .مجلة

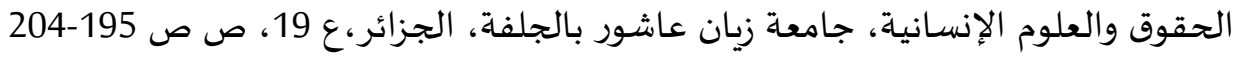
توق، مجي الدين؛ قطامي، يوسف؛ عدس، عبد الرحمن. (2003م). علم النفس التربوي، ط3، المقان المملكة الأردنية الهاشمية، عمان، دار الفكر. جورج، جورجيت دميا (2009م). متطلبات المكتبة المدرسية ودعامة تحقيقها أساسية لتلاميذ المستقبل، المؤتمر

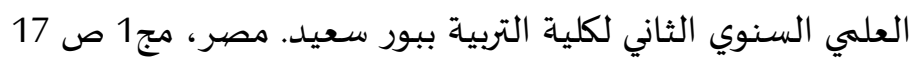
الحمد، أيمن بن أحمد (1435هـ). دور شبكات التواصل الاجتماعي في دعم المنظومة التعليمية لدى طلاب كلئ كلية

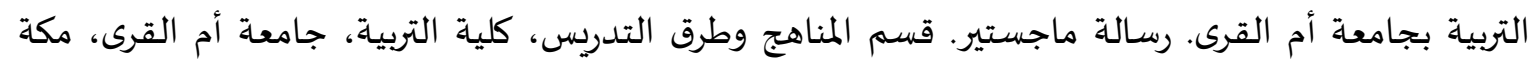

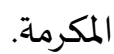

الخالدي، أديب (2003). سيكولوجية الفروق الفردية والتفوق العقلي. عمان: داروائل للنشر والتوزيع.

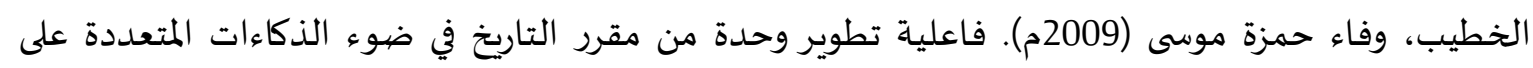

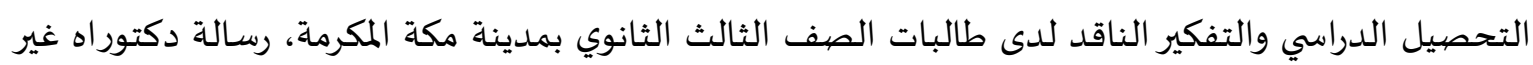
منشورة، قسم المناهج وطرق التدريس، كلية التربية، جامعة أم القرى، مكة المكرمة. الخليفة، هند بت سليمان (2006م). توظيف تقنيات ويب 2.0 في خدمة التعليم والتدريب الالكتروني، ورقة المانة علمية مقدمة بالمؤتمر التقني السعودي الرابع للتدريب المني والتقني الرياض، المملكة العربية السعودياة.

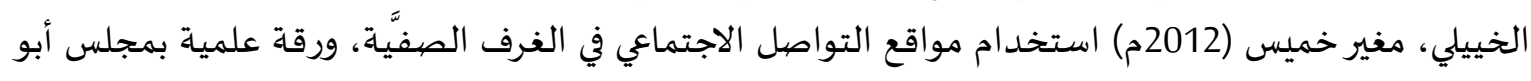
ظبي للتعليم، أبو ظبي، الإمارات العربية المتحدة.

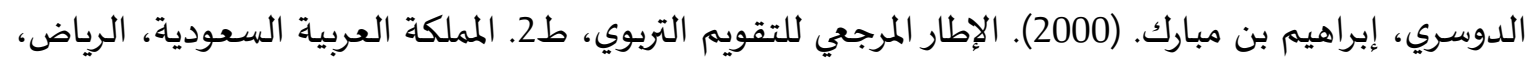
مكتب التربية العربي لدول الخليج. ربيع، هادي مشعان؛ الكبيسي، عبد الواحد حميد. (2008م). الاختبارات التحصيلية المدرسية (أسس بناء

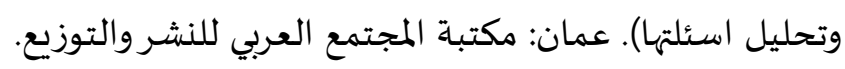
الرشيدي، سلطان نواف (2012م). درجة استخدام اعضاء هيئة التدريس في جامعة حائل لمواقع التواصل الاجتماعي في العملية التعليمية، رسالة ماجستير غير منشورة، جامعة اليرموك، الأردن

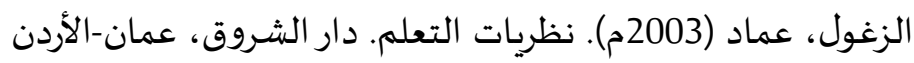

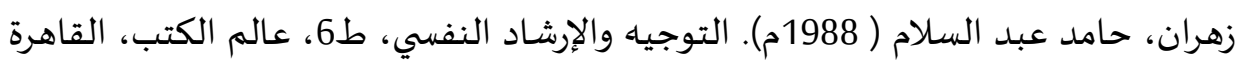

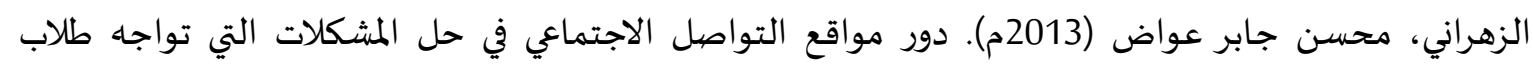
التربية العلمية واتجاهاتهم نحوها، رسالة دكتوراه غير منشورة. قسم المناهج وطرق التدرئ التهري، كلية التربية، جامعة أم القرى، مكاة المكرمة. 
- الزومان، آلاء بنت سعود (1433هـ). تعرض الشباب السعودي لوسائل الإعلام الجديد دراسة وصفية ميدانية على عينة من الطلاب والطالبات الجامعيين في مدينة الرياض، رسالة ماجستير غير منشورة، كلية الدعوة والإعلام، قسم الإعلام، وزارة التعليم العالي، جامعة الإمام محمد بن سعود الإسلامية، ، المملكة العربية السعودية

زيتون، كمال عبد الحميد (2000م). تدريس العلوم من منظور البنائية، الإسكندرية: المكتب العلمي للنشر والتوزيع.

زيتون، كمال عبد الحميد (2004). تصميم التعليم للكبار: منظور بنائي، مجلة العلوم التربوية، معهد الدراسات التربوية، جامعة القاهرة، العدد الثاني، أبريل.

السعدني، محمد عبد الرحمن، وحسين، هشام بركات (2012م). فاعلية استخدام الشبكات الاجتماعية في تحقيق التنمية المهنية المستدامة دراسة حالة على معلمي الرياض ببعض المدارس الابتدائية، مجلة جامعة طيبة للعلوم التربوية، عدد خاص ببحوث التعليم المستمروتحديات مجتمع المعرفة. محمود، خالد وليد (2011م). شبكات التواصل الاجتماعي وديناميكية التغير في العالم العربي، بيروت: مدارك المعردئ للنشر. المنصيور، محمد (2012م). تأثير شبكات التواصل الاجتماعي على جمهور المتلقين دراسة مقارنة للمواقع

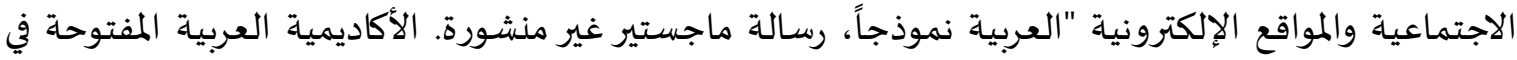
الدانمارك مجلس كلية الآداب والتربية.

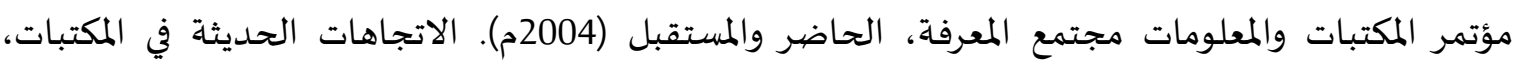
القاهرة، ع 22. ص ص ع 249. هنداوي، أسامة، وكابلي، طلال (2013م). دراسة مقارنة لاتجاهات هيئة التدريس والطلاب بجامعة طيبة نحو

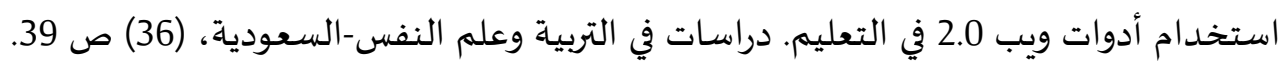

ثانياً - المراجع بالإنجليزية:

- Alshammari, F. (2014). "The perception on the use of Facebook for social learning among preservice teachers in Saudi Arabia". journalijar.com. 2, 7, 688-693.

- Baker, V, Paul, J., Cochran, J. (2012). Effect of Online Social Networking on Student Academic Performance. Computers in Human Behavior, 28 (6), 2117-2127.

- Barseghian, Tina (2011). 28 Creative Ideas for Teaching with Twitter, link: http: //www.bestcollegesonline.com/blog/2011/07/06/28-creative-ways-teachers-are-using-twitter

- Bosch, T. E. (2009). Using online social networking for teaching and learning: Facebook use at the University of Cape Town. Communicatio: South African

- Calvani, A., Bonaiuti G., \& Fini, A. (2008). Lifelong learning, what role for e-learning 2.0, Journal of elearning and Knowledge Society, 4 (1).

- Coklar, Ahmet. (2012). Evaluations of Students on Facebook as an Educational Environment. Turkish Online Journal Of Qualitative Inquiry, 3 (2), $42-53$

- Euronews. (2011). Social Media in the classroom. SPECIAL REPORTS. Retrieved Febuary 23, 2013 from http://www.euronews.com/2011/04/11/socialmedia-in-the-classroom/ 
- Grosseck, G. (2009). To use or not to use Web 2.0 in higher education.Procedia- Social and Behavioral Sciences, I (1). pp 478-482.

- Helou, Zor, Ab.Rahim, Zairah (2012). Students' Perceptions on Social Networking Sites Influence on Academic Performance, International Journal of Social Networking and Virtual Communities (Int J SocNet \& Vircom- Vol. 1, No. 1, pp. 7 15

- Junco, R.\& cotton, S. R. (2012). The Relationship between Multitasking and Academic performance. Computers \& Education,59 (2),505-514.

- Junco, R.\&others. (2011). The effect of Twitter on college student engagement and grades. Journal of Computer Assisted Learning.Volume 27, Issue 2, p119-132,

- Junco, R. (2012b). Too much face and not enough books: The relationship between multiple indices of Facebook use and academic performance. Computers \& Education, Vol.58, pp.187-198.

- Karbiniski, Aren (2010). Facebook and the technology revolution, N,Y Spectrum Publications.

- Kayri, M., \& Çakır, Ö. (2010). AN APPLIED STUDY ON EDUCATIONAL USE OF FACEBOOK AS A WEB 2.0 TOOL: THE SAMPLE LESSON OF COMPUTER NETWORKS AND COMMUNICATION. International Journal of Computer Science \& Information Technology, 2 (4), 48-58

- Ketari, L., \& Khanum, M. (2013). IMPACT OF FACEBOOK USAGE-ON THE ACADEMIC GRADES: A CASE STUDY. Journal Of

- Kinschner, Paul \& Karpinski, Aryn (2010): Facebook and academic performance. Computers in Human Behavior, 26 (2010), 1237-1245.

- Mazer, J.P., Murphy, R. E. \& Simonds, C.J., (2009). The effects of teacher self-disclosure via facebook on teacher credibility, learning, media and technology, 34, 2 .

- Mazman, S,Guzin, Usluel (2010). Gender Differences in Using social Nerworks. Turkis online journal of Educational Technology - tojet, v10 n2 p133-139

- Mehmood, Taswir, (2013). The Effects of Social Networking Sites on the Academic Performance of Students in College of Applied Sciences, Nizwa, Oman, International Journal of Arts and Commerce Vol. 2 No. 1

- O'Reilly, Tim (2005). What Is Web 2.0 Design Patterns and Business Models for the Next Generation of Software. [online] http://www.oreillynet.com/lpt/a/6228

- Oye, N., Helou, A.M. and Rahim, Z.Z.A. (2012), "Students' Perceptions on Social Networking Sites Influence on Academic Performance", International Journal of Social Networking and Virtual Communities, Vol. 1, No. 1, pp. 7-15

- Paul A., K., karpinski C., K. (2010). Facebook ${ }^{\circledR}$ and academic performance.Computers In Human Behavior, 26 (6), PP 1237-1245.

- Petrovic, N., petrovic, D., jeremic, V., Milenkovic, N. \& Cirovic, M. (2012). Possible Educational Use of Facebook in Higher Environment Education. Serbia. University at Belgrade 